Research Report No. 2/2009

\title{
Polygamy's Inscrutable Secular Mischief
}

Susan G. Drummond

Osgoode Hall Law School of York University, sdrummond@osgoode.yorku.ca

Follow this and additional works at: http:/ / digitalcommons.osgoode.yorku.ca/clpe

\section{Recommended Citation}

Drummond, Susan G., "Polygamy's Inscrutable Secular Mischief" (2009). Comparative Research in Law \& Political Economy. Research Paper No. 2/2009.

http://digitalcommons.osgoode.yorku.ca/clpe/117 


\section{Comparative Research in Law \& Political Economy}

\section{Susan G. Drummond}

Polygamy's Inscrutable Secular Mischief

EDITORS: Peer Zumbansen (Osgoode Hall Law School, Toronto, Director, Comparative Research in Law and Political Economy, York University), J ohn W. Cioffi (University of California at Riverside), Lindsay Krauss (Osgoode Hall Law School, Toronto, Production Editor) 

CLPE Research Paper 02/2009

Vol. 05 No. 01 (2009)

\title{
Susan G. Drummond
}

\section{Polygamy’s Inscrutable Secular Mischief}

\begin{abstract}
This paper attempts to decipher the specific mischief in the offence of polygamy in-and-of-itself. It examines whether the offence coincides any longer with the contemporary substratum of values about the family and sexuality that have emerged over the last forty years in Canadian law and society. The relevance of formal conjugality - triggered by marriage, extinguished by divorce, and shielded in-between by privacy - has been turned inside/out by the sociological and legal significance of functional conjugality. For the latter construct the content of intimate and familial relationships has become a substitute focus of legal scrutiny. Meanwhile, the contemporary range of normalized sexual and familial diversity has voided functional conjugality of the bright line coherence of its antecedent. Conjugality itself appears to be collapsing into uncertainty and incoherence in its most familiar domain: family law. These parallel developments in the socio-legal conception of family and intimacy have outpaced a polygamy offence that has sat virtually unused since the first Criminal Code of 1892. As a result, the polygamy offence itself has collapsed into the disintegrating concept of conjugality, rendering the harm that it targets all the more inscrutable. In the result, the polygamy section is void for vagueness and resultantly an infringement on liberty rights guaranteed in section 7 of the Canadian Charter of Rights and Freedoms. The inscrutability of polygamy's mischief suggests that criminal law is the wrong instrument for addressing worries about the vulnerabilities of women and children within plural family arrangements. These legitimate anxieties can be addressed through a plethora of alternative regulatory means, none of which assail fundamental principles of justice entrenched in the constitution.
\end{abstract}

Keywords: Polygamy; Void for vagueness; Conjugality; Religious marriage; Section 7, Charter of Rights and Freedoms;

JEL classification: K10, K36 


\section{Author Contact:}

Susan G. Drummond

Osgoode Hall Law School, York University

4700 Keele St, Toronto, Ontario, M3J 1P3

Email: sdrummond@osgoode.yorku.ca 


\title{
Polygamy’s InSCRUTABLe SEcUlar Mischief
}

Polygamy

\author{
Susan G. Drummond*
}

(1) Every one who

(a) practises or enters into or in any manner agrees or consents to practise or enter into

(i) any form of polygamy, or

(ii) any kind of conjugal union with more than one person at the same time, whether or not it is by law recognized as a binding form of marriage, or

(b) celebrates, assists or is a party to a rite, ceremony, contract or consent that purports to sanction a relationship mentioned in subparagraph (a)(i) or (ii),

is guilty of an indictable offence and liable to imprisonment for a term not exceeding five years. ${ }^{1}$

\section{SEXUAL EXPLOITATION, SEXUAL INTERFERENCE AND UNDERAGE MARRIAGE}

The polygamy charges ${ }^{2}$ that were laid in January of 2009 against two men, both members and leaders of the Fundamentalist Church of Jesus Christ of the Latter Day Saints (FLDS) in Bountiful, British Columbia, ought to stimulate a large scale re-thinking of how Canada conceives, and should conceive, of legitimate intimacy and the legitimate family. They will also push us into new understandings of the relationship

\footnotetext{
* Associate Professor, Osgoode Hall Law School. I am grateful to Bruce Ryder, Mary Jane Mossman and Angela Campbell for their helpful feedback on an earlier version of this paper. I would also like to express my appreciation to my colleagues at Osgoode Hall Law School who attended the presentation of an earlier version of this paper and provided useful discussion and feedback.

${ }^{1}$ Section 293, Criminal Code, R.S.C. 1985, c. C-46; hereinafter Criminal Code

2 See Robert Matas and Wendy Stueck, "Polygamy charges in Bountiful” Globe and Mail Update and The Canadian Press, January 7, 2009
} 
between state and religious minorities (and other norm-generating communities).

The re-evaluation stimulated by the charges may eventually lead to a preservation of the status quo through a judicial upholding of the Criminal Code's “Offences Against Conjugal Rights” at section 293. It may lead to only a minor modification of the status quo should the courts (as many expect) find that the polygamy section cannot withstand constitutional scrutiny under ss. 2, 7, or 15 of the Charter, ${ }^{3}$ with Parliament forced to come up with a more precise secular definition of polygamy that skirts the human rights pitfalls into which the current provision appears poised to fall.

Or - more self-conscious and informed following the crucible of political and legal scrutiny triggered by the charges - Parliament may find itself facing the stark reality of what Canadian family and intimate life has come to look like over the last 40 years since the 1968 Divorce Act and Prime Minister Trudeau's ushering of the state from the bedrooms of the nation's consenting adults. It may find - as I will argue is most likely that the sociological, jurisprudential, and legislative shifts of the last four decades have placed Parliament in a position such that it cannot identify a specific secular mischief in polygamy that is not simultaneously permitted elsewhere in law.

Given the religious background of the two accused and the fact that their faith already figures prominently in the public stance taken by the defense, ${ }^{4}$ the cases should stimulate far more than a review of the place of polygamous relationships within the growing diversity of legitimate Canadian family structures. The minority religio-cultural dimension of the Bountiful cases will come more clearly into focus precisely because of polygamy's inscrutable secular mischief. In light of the vagueness and overbreadth of the current legislation, I will argue that the state has left itself free to launch a standardless sweep driven by the personal predilections of law enforcement officials; predilections which appear to have set religious minorities within their sights.

\footnotetext{
${ }^{3}$ Constitution Act 1982, (U.K.) 1982, c. 11; hereinafter the Charter

4 “Bountiful leader calls polygamy charge 'religious persecution'” CBCNews.ca, Thursday, January 8, 2009; see http://www.cbc.ca/canada/britishcolumbia/story/2009/01/08/bc-polygamy-winston-blackmore.html, accessed January 15, 2009
} 
The vociferous crowd that is exhorting Wally Opal, the Attorney General of British Columbia, to forge on with the prosecutions are convinced that whether or not there is a deep harm associated with polygamy in-and-of-itself, the relational arrangement is a Gordian knot into which are inextricably tangled very grave social harms such as the sexual exploitation of and sexual interference with minors, the marriage of underage children to adults, and the subjugation and oppression of women. ${ }^{5}$

In this climate of generalized anxiety about possible misconduct in the community of Bountiful, it is important to point out that not a single charge has been laid for these latter harms, only two of which - sexual exploitation and sexual interference - constitute criminal offences.

Sexual exploitation (section 153 of the Criminal Code) prohibits an adult from having sexual contact with a young person between the ages of sixteen and eighteen toward whom the adult is in a "position of trust or authority" or a "relationship of dependency" or a relationship that is "exploitative" of a young person. ${ }^{6}$ Sexual Interference (under section 151 of the Criminal Code) is aimed at "Every person who, for a sexual purpose, touches, directly or indirectly, with a part of the body or with an object, any part of the body of a person under the age of sixteen years."7 If evidence exists that men in Bountiful have sexually exploited or interfered with young people, charges should be laid under these sections of the Criminal Code. The religious background of the defendants is irrelevant to the efficacy of these charges. Religious freedom, protected under section 2(a) of the Constitution Act of 1982, does not extend far enough to protect religious practices that harm the integrity of young people in this particularly pernicious way.

However none of the three special prosecutors that the Attorney General has hired, one after the other, to ferret out evidence of crimes and

\footnotetext{
${ }^{5}$ See Committee on Polygamous Issues, Life in Bountiful - A report on the lifestyle of a polygamous community, funded by the B.C. Ministry of Women's Equality (April 1993); Daphne Bramham, The Secret Lives of Saints: Child Brides and Lost Boys in Canada's Polygamous Mormon Sect (Toronto: Random House, 2008)

${ }^{6}$ R.S., 1985, c. C-46, s. 153; R.S., 1985, c. 19 (3rd Supp.), s. 1; 2005, c. 32, s. 4; 2008, c. 6. 
misdemeanors in Bountiful have uncovered sufficient evidence to prosecute. ${ }^{8}$ As defense has shrewdly elected to proceed with a trial in the Superior Court of British Columbia, ${ }^{9}$ the crown is precluded from going on a fishing expedition for more evidence of alleged lateral offences through a preliminary inquiry. ${ }^{10}$

Whether or not the subjugation and oppression of women (writ large) should be a criminal offence, I will leave to those more ideological driven than myself. As to the other tangle in polygamy's Gordian knot, underage marriage is not a criminal offence in Canada. Further, the "deplorable state of the law" common law to determine the age of consent to marriage, an antiquated body of law which permits Canadian children to marry at age 7 , the marriage being merely voidable until the age of 12 for girls and 14 for boys, after which point it becomes fully valid. ${ }^{12}$

As a result of these various disqualifications, polygamy in-and-ofitself remains the focus of criminal inquiry in the Bountiful cases, effectively disentangled from any presumed knot of broader criminal intrigue.

This paper attempts to decipher the specific mischief in the offence of polygamy in-and-of-itself. It examines whether the offence coincides any longer with the contemporary substratum of values about the family

${ }^{8}$ See, for example, Richard C.C. Peck, Q.C., Report of the Special Prosecutor for Allegations of Misconduct Associated with Bountiful, B.C.: Summary of Conclusions, online:

<http://www.canada.com/vancoubersun/news/extras/bountiful.pdf>

${ }^{9}$ See http://www.canada.com/topics/news/story.html?id=1202730

${ }^{10}$ E.g. by calling women and other members of the community to testify under oath about any and all evidence relevant to the presumed harm of polygamy.

${ }^{11}$ See Simon R. Fodden, Essentials of Canadian Law: Family Law (Toronto: Irwin Law, 1999) at 20

${ }^{12}$ Ibid at 20; see also Mary Jane Mossman, Families and the Law in Canada; Cases and Commentary, (Toronto, Emond Montgomery Publications Ltd) 2004 at 81; Berendt Hovius, Family Law: Cases Notes and Materials (Toronto: Carswell, 2005) at 131 
and sexuality that have emerged over the last forty years in Canadian law and society. The relevance of formal conjugality ${ }^{13}$ - triggered by marriage, extinguished by divorce, and shielded in-between by privacy - has been turned inside/out by the sociological and legal significance of functional conjugality. ${ }^{14}$ For the latter construct the content of intimate and familial relationships has become a substitute focus of legal scrutiny. Meanwhile, the contemporary range of normalized sexual and familial diversity has voided functional conjugality of the bright line coherence of its antecedent. Conjugality itself appears to be collapsing into uncertainty and incoherence in its most familiar domain: family law. ${ }^{15}$

These parallel developments in the socio-legal conception of family and intimacy have outpaced a polygamy offence that has sat virtually unused since the first Criminal Code of 1892. As a result, the polygamy offence itself has collapsed into the disintegrating concept of conjugality, rendering the harm that it targets all the more inscrutable.

The inscrutability of polygamy's mischief suggests that criminal law is the wrong instrument for addressing worries about the vulnerabilities of women and children within plural family arrangements. These very legitimate anxieties can be addressed through a plethora of alternative regulatory means, none of which assail fundamental principles of justice entrenched in the constitution. The offence of polygamy, on the other hand, has been left constitutionally exposed by the tectonic shifts in Canadian society.

\footnotetext{
${ }^{13}$ By formal, I mean state-generated, i.e. civil marriage.

14 To track developments in this direction, see Bruce Ryder and Brenda Cossman, "The Legal Regulation of Adult Personal Relationships: Evaluating Policy Objectives and Legal Options in Federal Legislation” Law Commission of Canada, 2000; and "Beyond Conjugality” Law Commission of Canada, 2001

${ }^{15}$ See Brenda Cossman \& Bruce Ryder, "What is Marriage-Like Like? The Irrelevance of Conjugality” (2001)18 Can. J. Fam. L. 269 - an article to which I will return towards the end of this paper.
} 


\section{ChARTER TROUble}

With polygamy left to carry the load in the Bountiful cases, deciphering its specific harm will become the central preoccupation of both the cases and the nation. This focus will be more concentrated given the way that the cases appear to be shaping up.

It is commonly believed that the defense will seek to invalidate the polygamy provision on the grounds that it violates the Charter. ${ }^{16}$ That the case will move so swiftly to a Charter challenge derives from the fact that at least one of the defendants, Winston Blackmore, has long and loudly been publicly broadcasting the fact that he has been performing celestial unions which usher women into plural marriages and that he himself is in such a plural marriage as the sole husband to multiple wives. ${ }^{17}$ His strategy appears to be to admit to the offence and to move straight for a Charter nullification. ${ }^{18}$ Deciphering the harm in polygamy will thus demand a broader order of inquiry, beyond the community of Bountiful, as the crown is compelled to locate the pressing and substantial objective that drives the legislation, one that must be capable of overriding a variety of human rights at stake in the prosecutions.

Just as commonly as it is believed that these cases will result in a Charter challenge, it is assumed that the approach most likely to succeed will be rooted in the claim that s.293 of the Criminal Code violates the right to religious freedom, guaranteed by section 2(a) of the Charter. ${ }^{19}$

A Charter challenge to s. 293 under s. 7 of the Charter (the right to

16 See the position of the BCCLA, for example, as voiced in http://www.bccla.org/othercontent/04.bountifulrussell.htm. See also pp 19 et seq of the report, "Expanding Recognition of Foreign Polygamous Marriages: Policy Implications for Canada" written by Martha Bailey, Beverly Baines, Bita Amani, and Amy Kaufman for the Status of Women Canada, Polygamy in Canada: Legal and Social Implications for Women and Children; A Collection of Policy Research Reports (Ottawa: Status of Women Canada, 2005)

${ }^{17}$ See, for example, the lengthy 2006 CBC documentary, "Bust-up in Bountiful”; online at: http://www.cbc.ca/fifth/bustupinbountiful/video.html

${ }^{18}$ See http://www.canada.com/topics/news/story.html?id=1202730

${ }^{19}$ See, for example, Martha Bailey et al, supra, note 16. 
life, liberty, and security of person) is thought by some legal scholars to be less powerful for the Bountiful cases. ${ }^{20}$ Such a challenge, it is assumed, would focus on the liberty interest in section 7 as it engaged with civil law, specifically the civil definition of marriage. The Supreme Court of Canada has found that liberty is infringed when the law prevents a person from making "fundamental personal choices". ${ }^{21}$ The right to choose whom one marries would be one such paradigmatic fundamental personal choice.

Under this argument, the liberty to choose to marry both religiously and polygamously is broad enough to capture the Bountiful situation, but broader, perhaps, than need be for those particular cases. The liberty right guaranteed under s. 7 may be more fitting for an independent challenge to the civil definition of marriage in the Civil Marriage Act that defines marriage, for civil purposes, as the lawful union of two persons to the exclusion of all others. ${ }^{22}$

While these are the most common Charter arguments that have been made out, I argue, in this paper, that there is another very compelling section 7 argument that can be raised - one, I believe, that is fatal for the constitutionality of s.293 of the Criminal Code.

In my assessment, the polygamy offense is both vague ("void for uncertainty") and overbroad, and is therefore a fundamentally unjust violation of the liberty right in s.7 of the Canadian Charter of Rights and Freedoms. Given that a conviction pursuant to s.293 can lead to imprisonment for up to five years, the section carries a far graver threat to liberty than state interference with fundamental personal choices. I will argue that the Criminal Code provisions relating to polygamy, already problematically drafted in 1892, have not kept apace with the effects of federal divorce law following 1968, nor with socio-legal developments in the structure of the family, nor with other developments within criminal law. In the language of the leading case on the void for vagueness doctrine, the "substratum of values" that underlies legal enactments and

\footnotetext{
${ }^{20}$ Supra, note 16 at p. 39;

21 Blencoe v. British Columbia, [2000] 2 S.C.R. 307 at paras $49-54$ and cases cited therein.

${ }^{22}$ Civil Marriage Act S.C., 2005, c. 33; hereinafter Civil Marriage Act; for this section 7 analysis, see pp 30 et seq of Bailey et al, supra, note 16.
} 
provides the substantive content of fair notice has shifted considerably over the last 40 years. ${ }^{23}$ The polygamy provision is no longer coincident with that substratum.

In light of socio-legal developments since the polygamy laws were drafted, it is now almost impossible for citizens to foresee what conduct they must avoid in order to remain beyond the reach of s.293. Where citizens are potentially liable to being deprived of their liberty (for up to five years in the case of the polygamy provisions), such reasonable foreseeability is critical to ensuring that deprivations of liberty are in accord with the principles of fundamental justice. ${ }^{24}$

The argument that s.293 is vague and overly broad is not unrelated to claims that might be made with respect to religious freedom, nor to the argument that the polygamy law discriminates on the grounds of religious belief. Any criminal law that is problematically vague or overbroad leaves socially and politically marginalized groups vulnerable to standardless sweeps driven by the personal predilections of law enforcement officials. In the case of the polygamy laws, this anxiety seems particularly apt in light of the history of how they came about.

The historical origins of the polygamy offence are rooted in Ecclesiastical policy that goes back to the $13^{\text {th }}$ century; rooted, in other words, in the particular vision for society of a particular religious group one that happened to be dominant when the laws were promulgated. At the private law level, Canada entered confederation with a common law definition of marriage that was embedded in the very case that was finally overturned in the flurry of same-sex marriage challenges in the 2000s. ${ }^{25}$ The Hyde case, now constitutionally objectionable for its restriction of marriage to one man and one woman, was in fact a case about polygamy, the emphasis in the original case being on one man and one woman. Hyde laid down for all Canadians the civil prohibition on the recognition of polygamous marriages by clearly enunciating the presumed ecclesiastical

${ }^{23}$ R. v. Nova Scotia Pharmaceutical Society,[1992] 2 S.C.R. 606 at para 48; hereinafter Nova Scotia Pharmaceutical Society

${ }^{24}$ See Reference re ss.193 and 195(1)(1)(c) of the Criminal Code (Canada) (1990), 56 C.C.C. (3d) 65 at para 86; hereinafter Prostitution Reference

${ }^{25}$ Hyde v. Hyde and Woodmansee, (1866), L.R. 1 P. \& D. 130; hereinafter Hyde 
motif for all legitimate marriage: "Marriage as understood in Christendom is the voluntary union for life of one man and one woman, to the exclusion of all others.” (Italics added). This definition prevailed in Canada from 1866-2005. The prohibition on plural unions for civil marriages is now embedded in the Civil Marriage Act of 2005, minus all reference to religiosity. ${ }^{26}$

The fact that Hyde's definition of marriage means so many different things depending on the change of emphasis - and that it resonates with meanings today that would not have been conceivable when penned - is indicative of some of the massive sociological shifts that have rendered the Criminal Code polygamy offence obsolete.

The very explicitly Christian context of Canadian family law is evident in Canada's civil understanding of polygamy and monogamy. The setting up of religious minorities (and their conceptions of marriage) as outliers to the dominant religious affiliation of the nascent state is evident from the fact that the plaintiff in the Hyde case was (like the defendants in the Bountiful cases) a Mormon. Given that, in the words of the judge, "the matrimonial law of this country is adapted to the Christian marriage", a marriage under Mormon law was grouped with marriages formed among "infidel nations" - a formation beyond the collective pale.

While this ecclesiastical stance on bigamy and polygamy was embodied in criminal law legislation in 1885 and 1890 respectively, ${ }^{27}$ in 1892 the polygamy provisions consolidated the particularity of their religious distastes (against Mormons) just two years after the Mormons in the United States split between the now majority sect that renounces polygamous marriage and the FLDS which has insisted throughout on the legitimacy of plural marriage. The two accused in the Bountiful cases are both members of the FLDS.

The US Congress passed legislation in 1882 outlawing bigamy and polygamy in the US Territories. In 1889, FLDS Mormons fled the United States, seeking refuge in British Columbia and Alberta. Under pressure from the Americans to follow suit in criminalizing specifically Mormon polygamy, the Canadian Parliament inserted a clause in the polygamy

\footnotetext{
26 "Marriage, for civil purposes, is the lawful union of two persons to the exclusion of all others."(Italics added) Section 2, Civil Marriage Act

${ }^{27}$ Supra, note 16 at note 93
} 
provisions that specifically referred to Mormons; a clause that was not removed from the Criminal Code until $1954 .^{28}$

In their report to the Status of Women Canada, Bailey et al argue that "the prohibition's ecclesiastical origin as well as its express reference to Mormons suggests that its pressing and substantial objective is to serve a religious purpose."29 Even if the more contemporary justification for a prohibition on polygamy stems from concerns about the vulnerabilities of women and children, "the Supreme Court of Canada will not entertain shifting purposes, meaning that the government can rely only on the purpose that animated the provision when it was enacted." 30 They argue that in the face of a finding that the prohibition on polygamy infringes section 2 rights to freedom of religion, the Crown will have difficulty establishing that the impugned provision is of sufficient importance under section 1 to warrant overriding a constitutionally protected right. The animating religious objectives of the legislation - even if now suffused with a concern for the equality rights of women - are unlikely to be considered pressing and substantial enough, the law of this country long having come out from under the shadow of Christian marriage.

This argument about the shifting purposes of the polygamy provisions may not ultimately hold much water implying, as it does, that Parliament is precluded from embodying new social objectives in modified, though used, legislative flasks. To be compelling, this argument would need to establish that religious objectives continue to animate the legislation. The fact that the Criminal Code was amended in the 1950s to remove explicit references to a now prohibited religious objective would suggest that the original anti-Mormon animus of the section has been expunged.

However those who argue that the original religious purpose has been overtaken by the pressing and substantial purpose one of protecting vulnerable women and children within plural unions ${ }^{31}$ may face just as

\footnotetext{
${ }^{28}$ See Bailey et al, supra note 16, at p. 23.

${ }^{29}$ ibid

${ }^{30}$ ibid; Bailey et al rely upon both R. v. Big M Drug Mart Ltd, [1985] 1 S.C.R. 295 and R. v. Zundel, [1992] 2 S.C.R. 731) for their "shifting purposes” argument.

31 See Nicholas Bala’s argument in “An International Review of Polygamy: Legal and Policy. Implications for Canada” (research paper for Status of Women Canada, 2005) and
} 
difficult a challenge in establishing that the government was preoccupied with this guiding concern in $1954 .^{32}$ The amendment that dropped the reference to Mormons in 1954 was part of a general overhaul of the Criminal Code in the early 1950s to modernize its content and remove, throughout, antiquated formulations and offences. As per the reasoning in Big M Drug Mart, deciphering the purpose of legislation hinges upon "the intent of those who drafted and enacted the legislation at the time."33 The Crown is precluded from ascribing a new purpose to legislation in the course of Charter litigation. Arguments that reference a child and womancentered preoccupation underlying s. 293 will need to square this conception of polygamy's paramount harm with legislative history.

The legislative history of the polygamy section may, in any event, be of diminished importance with respect to its constitutionality. Even if the guiding concern of protecting women and children were acknowledged to be its pressing and substantial aim, the contemporary objective of protecting women and children may in fact be far more easily, effectively, and fairly met through other laws and social policies more rationally connected with this goal than the criminalization of polygamy. ${ }^{34}$ The extraordinary vagueness and overbreadth of the polygamy provisions generates a very high threshold to meet in order to justify the violation of s.7 liberty rights, a threshold that is reinforced by the abundance of ways to meet the objective that harm neither religious freedom, nor liberty, nor equality interests, nor fundamental justice.

In light of these arguments, harm to religious groups and minority communities becomes more salient and poignant. The odour of religious

Rebecca J. Cook with Lisa M. Kelly, "Polygyny and Canada's Obligations under International Human Rights Law”, Family, Children and Youth Section, Department of Justice Canada, 2006.

${ }^{32}$ Under the first branch of the Oakes test to determine which claims about limiting rights are justifiable under section 1 of the Charter: “The Canadian Charter or Rights and Freedoms guarantees the rights and freedoms set out in it subject only to such reasonable limits prescribed by law as can be demonstrably justified in a free and democratic society”. See Bala’s argument, ibid.

${ }^{33}$ R. v. Big M Drug Mart Ltd, [1985] 1 S.C.R. 295 at para 91

${ }^{34}$ This is argued in the last section of this paper. 
persecution lingers over the offence particularly when conjoined with the ways in which they have been historically directed or applied to socially and politically marginalized groups. The fear that a reasonable person would have difficulty discerning the mischief of polygamy is compounded by an historical predilection of the provision to target minority social groups. This history leaves a creepy aura of winking and nodding around s.293 to the effect that: although a vast number of us may be theoretically vulnerable to prosecution, most of us don't need to worry: it is "them" we are after.

\section{HOW VAGUE AND BROAD ARE THE POLYGAMY PROVISIONS?}

The polygamy provisions are vague and broad enough that it is true to say that I have committed polygamy. In fact I have declared so publicly in the national media. ${ }^{35}$ I was quite easily caught by the extraordinarily broad definition of polygamy in s. 293 which singles out "every one who enters into any kind of conjugal union with more than one person at the same time, whether or not it is by law recognized as a binding form of marriage."

Like 38\% of Canadians, I both married and divorced. Like many Canadians, I was somewhat nonchalant about the institution of marriage. As cohabitational relationships gather about them virtually all of the benefits of marriage and increasingly little social stigma, marriage has become a principally symbolic institution. While sorting out the incidentals of divorce (custody, support, etc.) was important to me, getting the actual divorce was not. Unlike the other weighty elements of Canadian family law, all a divorce enabled me to do was to remarry civilly. As I had no desire to remarry, I was living separate and apart from my "husband" for six years before I got a divorce. My marriage was, if nothing else, the paradigmatic "conjugal union."

Two years after my separation, I entered another "conjugal union" with my partner of the last seven years. This was not hard to do. The

\footnotetext{
35 "You really want them all charged? You might be surprised who would get caught in the dragnet”, The Globe and Mail, August 5, 2008
} 
definition of "conjugal union" in Canadian law is broad enough that an inordinate number of details have the potential to be simultaneously salacious and banal. The definition of conjugal union used to include things such as the sharing of meals, sexual exchange, watching TV together, and the delivery of domestic services. ${ }^{36}$ With sexual and domestic services sitting uncomfortably with the rights and obligations of conjugality, eating pizza with someone, while watching Sopranos reruns, could constitute the requisite factual nexus for a conjugal union.

Of course I am extraordinarily unlikely to be prosecuted for polygamy and we all know it. But this is not because this implicating scenario that I have laid out involves clever and improbable legal somersaults. In the first event, the intuition that I have nothing to worry about would not have been so evident 40 years ago when it would have extraordinarily brazen for a woman to nonchalantly announce in the national media that she was both a "divorcée" and living with a man in unmarried cohabitation. Imagine, indeed, how difficult it would have been for me to announce a mere 10 years ago that my child and I were conjugally cohabiting with a woman post-divorce; or a short four years ago that I was contemplating marrying her. Not long ago, I could well have been "the kind of person" that the polygamy laws were aimed at, the kind that dwells precariously on the outside of the officially constituted "we".

The religious history of the polygamy provisions, their extraordinary vagueness, the voices rising from today's vociferous crowd, and the fact that the 1892 offence has come full circle now in charges against two Mormons, suggests that I happen to be safe this time because I don't happen to be "the kind of person" who is a member of a minority religious group.

It might be tempting to assume that the scenario I have raised about my own criminal liability is just idle speculation using a range of improbable hypotheticals tangentially related to the bare words of the statutory provision - just the kind of angels-on-pinheads arguments raised

${ }^{36}$ Molodowich v. Penttinen (1980)17 R.F.L. 9 (2d) 376; See also the string of cases relating to the criteria for living separate and apart while under the same roof for the purposes of s. 8(2)(a) of the Divorce Act: Rushton v. Rushton, (1968), 66 W.W.R. 764, 2 D.L.R. (3d) 25; Dupere v. Dupere (1974), 19 R.F.L. 270, 9 N.B.R. (2d) 554. The argument about the growing incoherence of the concept of conjugality is argued below. 
by legal academics. Surely no law would survive the void for vagueness test if absolute certainty were a prerequisite of validity. The Criminal Code would have to model the notoriously unwieldy and ephemeral Prussian civil code that had over 17,000 codal articles covering almost as many legal issues as facts.

Indeed, Justice Lamer, in one of the leading cases on void for vagueness, is clear that the doctrine does not require absolutely certainty in its formulation. Further, the doctrine "is not be applied to the bare words of the statutory provision but, rather, to the provision as interpreted and applied in judicial decisions." 37 The provisions, in other words, need to be read in light of relevant case law.

This is exactly what I intend to do in this article, demonstrating that the collective wisdom of the few scattered polygamy cases of last century has significantly voided the polygamy provisions of their intelligibility.

Canada's polygamy cases, however, have not single-handedly eviscerated polygamy of coherence. The criminal law does not exist as a silo next to the other silos of Canadian law. It has to be examined in the context of the areas of law that surround it - in the context of the Canadian legal system as a whole. This is particularly so when a Criminal Code provision refers to a concept such as "conjugal union" which is nowhere defined in the code but which has acquired its flesh and blood from developments within family law.

As the definition of polygamy is inextricably related through the concepts of "form of marriage" and "conjugal union” to the institutions of family law, this paper will begin its analysis with the way some of those key institutions are currently configured. I will show that in family law significant exceptions have been carved out of key phrases in the bigamy and polygamy provisions such that religious marriages on their own absent a factual nexus that elevates them to other legal indicia in the polygamy offence - are neither "conjugal unions" nor "forms of marriage" for the purposes of the criminal law. Polygamous unions are not formed by virtue of a simultaneous multiplicity of non-state ceremonies to different

\footnotetext{
${ }^{37}$ Supra, note 24, at p.30, citing Lebeau (1988) 62 C.R. (3d) 157 at 167; See also Nova Scotia Pharmaceutical Society; Canadian Foundation for Children, Youth and the Law v. Canada (Attorney General), [2004] 1 S.C.R. 76, 2004 SCC 4; Canada (Attorney General) v. JTI-Macdonald Corp., 2007 SCC 30, [2007] 2 S.C.R. 610
} 
partners.

Given that religious marriages on their own are "nullities" in Canadian law and have been excluded from two of the core concepts underpinning the Offences Against Conjugal Rights (“conjugal union” and "forms of marriage"), I will show that the state has no means of distinguishing monogamous from plural religious marriages for the purposes of both family and criminal law. Both de facto and in law, Canada tolerates plural religious marriages on its territory and cannot single out groups that practice a religious version of polygamy.

I will also show that the only principled (constitutional) definition of bigamy, - which prohibits those, already married to one party, from entering another "form of marriage" with another - must interpret "form of marriage" to mean "civil marriage". In other words, consistent with the Civil Marriage Act's definition of marriage "for civil purposes", the bigamy prohibition can only apply to parties entering two civil marriages with separate partners.

From an examination of where family law has taken us since the Divorce Act, I will turn to the polygamy jurisprudence itself to show that adulterous relationships are consistent with monogamy. On the basis of this antiquated jurisprudence, even a long-term cohabitational relationship with a party with whom one is raising children is consistent with a monogamous marriage (with children) to another. More adventuresome yet, the polygamy and bigamy provisions are consistent with promiscuous sexual activity involving oneself and/or one's spouse along with other couples and individuals.

Ultimately, given the way that all of these encroachments have left very little culpable behavior in the polygamy provisions, I will turn to family law's understanding of "conjugal union” - a concept that itself has deteriorated to the point that it can lend criminal law less than no assistance in deciphering problematic behavior; "less than no assistance" because criminal law judges are left to "knowing one when they see it". The latter mechanism for targeting criminal conduct is, of course, a wholly unacceptable criteria for criminal jeopardy.

Let me begin, then, by getting at one of family law's inaugural institutions: marriage formation. 
[VOL. 05 No. 01

\section{THE NULlity OF RELIGIOUS MARRIAGE}

Under the constitutional division of powers stemming from the 1867 Constitution Act, the federal Parliament has jurisdiction over marriage and divorce and the provincial legislatures have jurisdiction over the solemnization of marriage. Parliament only occupied its legislative authority to define marriage in 2005 when it generated a single substantive sentence in the Civil Marriage Act: "Marriage, for civil purposes, is the lawful union of two persons to the exclusion of all others.",38

Provincial legislatures retain the right to legislate the formal conditions for the validity of marriage; matters such as how many witnesses are required, whether a religious officiant can celebrate the marriage, and the ritual words that must be uttered in the creation of all valid civil marriages. Each province regulates these formalities in its own marriage (solemnization) act.

Canadian provinces have adopted a pluralistic model with respect to marriage officiants. Structured into the rules of marriage solemnization is a facility that bestows religious officials with the delegated authority of civil bureaucrats for the purposes of creating a civil marriage simultaneous with a religious marriage. ${ }^{39}$ The state has some say (though little) at this juncture about what constitutes a recognizable religious community and who, a qualified official. Not anybody from anywhere can occupy the delegated position of religious officiant of civil marriages. ${ }^{40}$

Under Canadian solemnization law, any religious marriage ceremony that takes place before, during, or after a civil solemnization is incidental and has no civil legal effect in and of itself. Indeed, the proper

\footnotetext{
38 Section 2, Civil Marriage Act. This sentence overturned, at the national level, the antecedent common law definition of marriage in Hyde. The few other sentences in the Civil Marriage Act are preambular or clarificatory and not substantive.

${ }^{39}$ For example, see section 20 of Ontario’s Marriage Act

${ }^{40}$ Ontario's Marriage Act, for example, stipulates that the officiant must be ordained or appointed according to the rites and usages of the religious body to which he or she belongs, must be recognized by their religious community as entitled to solemnize a marriage and must be resident in Ontario. Further, the religious community must have some continuity in Ontario. See section 20 Marriage Act, R.S.O. 1990, ch. M.3.
} 
characterization of these non-civil marriages is that they are legal nullities in the eyes of Canadian law. Celestial unions and marriages performed strictly according to Jewish, Muslim, or Catholic law, for example, are legally irrelevant for the civil law on their own. In the eyes of civil law, they have no different status from unmarried cohabitation - and they only rise to the latter status in the event that they otherwise meet the criteria set out in statutory definitions of cohabiting spouse.

For the state, it is as though a party to a real estate transaction claimed to create a right of ownership by tossing three gold coins in the air. As long as the real estate transaction is accompanied by all of the requisites in real estate law that create a valid transfer of ownership, the house is hers. Without meeting all of those requisites, tossing gold coins is a meaningless ritual as far as the state is concerned; and the secular state remains assiduously agnostic about whether the ritual has meaning outside of real estate law. Any potential civil consequence attributable to religious marriages arises by virtue of a state of fact that might incidentally accompany the marriage, such as a period of cohabitation that meets federal and provincial statutory requirements for a spousal relationship.

Canada's pluralism is distinguishable from the exclusively bureaucratic model of civil marriage in jurisdictions such as France, which only allows civil officials to create a valid civil marriage. But there are other hallmarks of Canada's pluralistic and tolerant approach to marriage formation that have implications for bigamy and polygamy as important as the civil nullity of religious marriage.

For Canada, religious celebration of marriage outside of civil solemnization is not prohibited. There is no requirement in provincial marriage (solemnization) acts or in other Canadian legislation that compels a religious community to nominate a civil officiant for all marriages concluded within that community, or compels individual couples within religious communities to get a civil marriage. In other words, nothing prohibits religious communities from conducting exclusively religious marriages, never solemnizing them civilly. The state has no say or interest in what constitutes such a religious marriage that has no contact with civil law, nor in who is qualified to perfect it.

Canadian tolerance for religious marriages transacted outside of the civil marriage framework can be contrasted with jurisdictions such as France, which prohibit (with penal sanctions) the celebration of a religious marriage prior or simultaneous to civil solemnization. The French Code Penal, for example, stipulates that "[a]ny minister of religion who 
habitually conducts religious ceremonies of marriages without being presented beforehand with the marriage certificate received by officials responsible for civil status is punished by six months' imprisonment and a fine of $€ 7,500$." 41

Canada has no such equivalent to France's “Offences Against the Civil Status of Persons” in its Criminal Code. It nowhere shares this deep aversion to the persistence of systems of religious marriage law alongside a civil registry of status. Marriage solemnization acts are concerned only with inaugurating couples into the legal framework of civil marriage. It invites Muslim, Christian (including Mormon), Jewish, and other religious communities, to have their officials sign up to serve as qualified civil functionaries for the formalization of marriage; it does not compel them to do so. ${ }^{42}$

The tentative implication of these features of Canada's marriage solemnization laws is that, as nullities, Canada de facto tolerates plural religious marriages within its territory. Religious marriages - all of them fly below the radar of civil concern. This is partly a feature of the fact that Canada has no mechanism for identifying informal plural unions when the parties have never intersected with the state by getting a civil marriage. However this technical difficulty (conjoined with the prospects that parties

${ }^{41}$ Article 433-21, Code Penal, J.O.R.F., Ordinance no. 2000-916 of 19 September 2000 Article 3 Official Journal of 22 September 2000 in force 1 January 2002. Cited in Legifrance,

42 There is an exception to this understanding that religious marriage ceremonies, in and of themselves, have no civil effect. Section 31 of the Ontario Marriage Act allows for parties who have solemnized their marriage in good faith, while intending to be in compliance with the Marriage Act, to apply to court to have their marriage deemed valid even if it failed to comply with all of the formal requirements of the Marriage Act. Validation is contingent upon living together and cohabiting "as a married couple”. A Muslim couple, for example, who married only religiously but who in good faith thought they were entering a valid marriage under Ontario legislation, might qualify to have their religious marriage retroactively deemed valid. However the phrase "intend[ing] to be in compliance with this Act” is critical for this validation. Those who marry religiously, intending the marriage to remain outside of the civil sphere, have marriages that are not formally valid in civil law, nor are they susceptible to retroactive validation. See Alspector v. Alspector [1957] O.R. 454 (Ont. C.A.) for a case of a Jewish couple, married in Ontario by a cantor, the wife being in good faith that the marriage was valid under Ontario law, the husband not, for an application of the retroactive validation in civil law of formally invalid religious marriage. 
might hide their marital status from state officials) presents merely practical impediments.

This pragmatic tolerance gets elevated to a legal tolerance when it is conjoined with both the civil nullity of religious marriage within Canada and with two Canadian conflict of laws rules that deal specifically with plural non-civil unions.

The first rule deals with plural unions celebrated by religious communities within countries that do not permit polygamy. Such arrangements are not marriages under civil law for the purposes of recognition of foreign marriage. No civil consequences flow from such a religious ceremony. ${ }^{43}$ Beyond plural religious marriages performed in other countries that prohibit polygamy, private international law regards marriages celebrated in Canada "in non-monogamous form without a preceding ceremony in accordance with Canadian provincial law [as]...nullit[ies]." ${ }^{44}$ Canadian private international law groups non-civil plural marriage with other forms of hocus pocus, just as real estate law take no greater cognizance of the tossing of six gold coins than it takes of three. A plurality of nullities amounts to a nullity.

Further, as we shall see, the scant criminal law jurisprudence on polygamy appears to suggest that cohabitational relationships are nullities for the purposes of the polygamy provisions; as religious marriages have no greater status in civil law than unmarried cohabitation, religious marriages are affected by the state's nonchalance towards both plural cohabitation and plural sexual unions. ${ }^{45}$ This entrenches Canada's legal tolerance for plural religious marriage and the understanding that a plurality of nullities is a nullity.

To put the implications of the civil nullity of religious marriage succinctly, they only cross the threshold of potential criminal liability when they as-a-matter-of-fact coincide with the status of unmarried cohabitation. It is only the factual nexus of conjugal cohabitation - that

\footnotetext{
${ }^{43}$ See Bailey et al, supra, note 16, at p.2

${ }^{44}$ Qureshi v. Qureshi, [1971] 1 All E.R. 325; see also Jean-Gabriel Castel and Janet Walker: Canadian Conflict of Laws, 6 ed looseleaf (Markham: Butterworths, 2005) at section 16.6

45 See below under the sections "Customary Marriage, Adultery, and Unmarried Cohabitation" and "Sexual Mischief”
} 
[VOL. 05 No. 01

may or may not be present within religious marriages - that transforms a plurality of religious marriages into polygamy. Where intuitively a plurality of simultaneous religious marriages to different people might seem to constitute "any form of polygamy" for the purposes of the polygamy section, the civil nullity of religious marriage reduces the content of the first subsection of the polygamy offence to little more than a tautological phrase: "Everyone who enters into any form of polygamy commits the indictable offence of polygamy." It is the legal construct of conjugal union that is left to do all of the polygamy offence's work. As we shall see, this construct is unendowed with the kind of cogency for which it is tasked in the polygamy section.

Before turning to the criminal law's own understanding of the mischief in plural unions, there is other evidence of Canada's legal tolerance for plural religious marriage that flows out of provincial marriage solemnization acts, particularly when read in conjunction with the universal jurisdiction of the federal Divorce Act of 1968; further evidence that a plurality of simultaneous religious marriages to separate partners do not constitute "any form of polygamy"; further evidence that the addition of "any form of polygamy" to the polygamy section adds nothing that is not covered by "any kind of conjugal union" and therefore collapses into a tautology.

The potentially discriminatory aspect of penalizing some forms of religious marriage and not others derives from the concept of a "lawful impediment" in provincial marriage (solemnization) acts, as interpreted in the face of the indissolubility of Catholic marriage through divorce and the legal status of women bound in Jewish marriages. As I will argue next, Canada does not regard Catholic and Jewish marriages as either "forms of marriage" or "conjugal unions" for the purposes of the bigamy and polygamy laws, even when conjoined with civil marriages to other parties - and so is in no position to regard other plural formations involving religious minorities as criminal. 


\section{LAWFUL IMPEDIMENTS}

Bigamy

(1) Every one commits bigamy who

(a) in Canada,

(i) being married, goes through a form of marriage with another person,

(ii) knowing that another person is married, goes through a form of marriage with that person, or

(iii) on the same day or simultaneously, goes through a form of marriage with more than one person; or

(b) being a Canadian citizen resident in Canada leaves Canada with intent to do anything mentioned in subparagraphs (a)(i) to (iii) and, pursuant thereto, does outside Canada anything mentioned in those subparagraphs in circumstances mentioned therein. ${ }^{46}$

Unlike France, Canada does not penalize the independent religious formation of marriage. The Canadian state is tolerant towards a flourishing of parallel marriage law regimes, regarding the latter as irrelevancies in civil law. It is further agnostic about the rituals religious groups engage in to celebrate religious marriage. Religious groups can generate their own criteria for the formal and essential validity of a religious marriage. So long as these rituals do not engage behavior that is otherwise prohibited for example sexual interference, sexual exploitation, or sexual assault the state is indifferent to religion's internal understandings of valid marriage formation:

Jewish marriages can be celebrated using the strictly contractual requirements of bilateral consent - a necessary condition that Western

\footnotetext{
${ }^{46}$ Section 290, Criminal Code
} 
Christian marriage abandoned as no longer sufficient in the $16^{\text {th }}$ century when it outlawed clandestine marriage and added the requirement for a third party celebrant, a priest. ${ }^{47}$ Jewish law can modify itself such that the presence of a rabbi becomes indispensable for the validity of Jewish marriage. The presence of a priest or rabbi remains relevant in Canadian only to the extent that provincial legislation recognizes their religion and authorizes their status as delegated civil officials. The Canadian state is indifferent to the requirement in Muslim marriage that a dower perfect the validity of the union, or the requirement in some sects that the bride's guardian consent to her marriage. Similarly the Canadian state is indifferent to whatever rituals are invoked to perfect a "celestial union". So long as no other Canadian laws are violated, the couple thus married can live out the rest of their lives untroubled by the state, without ever celebrating a civil marriage. If couples within religious communities wish to (also) enter civil marriage, provincial law regulates the interface.

Beyond the registration requirements that enable religious authorities to perform civil marriages, the other key formality required to perfect a civil marriage is the parties' certification that there is no "lawful impediment” to their marriage. ${ }^{48}$

One of the lawful impediments to a civil marriage is a prior existing marriage. ${ }^{49}$ A person must be unmarried at the time of the marriage ceremony. Further, in family law, a bigamous marriage is void

47 See Jean Gaudemet, Le Mariage en Occident: Les Moeurs et le droit (Paris: Les Éditions du Cerf, 1987); For historical materials in the Canadian context see also Mark D. Walters, "Incorporating Common Law into the Constitution of Canada: Egale v. Canada and the Status of Marriage”, (2002) Osgoode Hall Law Journal, Vol 41, No. 1, 75-112

48 See, for example, section 24(3) of the Ontario Marriage Act stipulates the following: "In some part of the ceremony, in the presence of the person solemnizing the marriage and witnesses, each of the parties shall declare: 'I do solemnly declare that I do not know of any lawful impediment why I, AB, may not be joined in matrimony to CD' and each of the parties shall say to the other: 'I call upon these persons here present to witness that I, $\mathrm{AB}$, do take you, CD, to be my lawful wedded wife (or to be my lawful wedded husband or to be my lawful wedded partner or to be my lawful wedded spouse).” I will be drawing on Ontario's Marriage Act to provide concreteness to the discussion relating to lawful impediments.

${ }^{49}$ See Fodden, supra, note 11 at p.23. 
$a b$ initio. Like a religious marriage, it carries no civil consequence in-andof-itself. ${ }^{50}$ Only the first marriage has civil effect.

The absence of a prior existing marriage is one of the essential conditions of valid marriage formation. As such it falls, like the age of consent to marriage, under Parliament's jurisdiction. It was not until 2005 that Parliament occupied its jurisdictional authority to define marriage with the Civil Marriage Act and when it did, it apparently could not have made it more clear that Canadians are only permitted one marriage at a time: "Marriage, for civil purposes, is the lawful union of two persons to the exclusion of all others." 51

The Civil Marriage Act could not be clearer about the civil prohibition on marriage to more than one person at the same time. What remains unclear about the Act is whether the existence of a prior existing religious marriage to one person is a lawful impediment to a civil marriage to another or whether, consistent with the above analysis of religious marriage as nullities, it is only prior existing civil marriages that preclude one from marrying civilly.

The language of the Civil Marriage Act appears to quite selfconsciously leave that question alone. The Act explicitly restricts its scope to marriage "for civil purposes". Further, the way that the term "lawful impediment" has been interpreted in law suggests that the civil prohibition on bigamy only applies to civil marriages - which, I will argue, is a proper interpretation.

On first blush my argument that the civil prohibition on plural marriage only speaks to plural civil marriage seems counterintuitive. On the surface, the requirement for each spouse to solemnly declare that they know of no lawful impediment to marriage would seem to suggest that

\footnotetext{
${ }^{50}$ That said, like adverse possession, there are mechanisms in law for spouses who, in good faith, thought they were entering a monogamous marriage to claim relief under provincial marital property regimes. See section 1 of the Family Law Act R.S.O. 1990, c. F.3; hereinafter the Family Law Act. They can also claim relief for spousal support under if their void marriage coincides with the requirements for unmarried cohabitation. See section 29 of the Family Law Act. Under this cohabitational umbrella, they are also eligible for third party benefits such as health benefits, CPP benefits, and insurance claims. See the federal government's Modernization of Benefits Act, S.C. 2000, c.12 and its provincial equivalents.

${ }^{51}$ Section 2, Civil Marriage Act.
} 
[VOL. 05 No. 01

religiously married spouses must declare the latter as a "lawful impediment” to civil marriage.

My argument seems particularly precarious in light of the reinforcement of Canada's civil prohibition against bigamous marriage in the criminal prohibition on bigamous marriage under section 290 of the Criminal Code. Bigamy is an offence directed at anyone who, being married, goes through any other "form of marriage" with another person. ${ }^{52}$ Surely a religious marriage is a "form of marriage", even if, as a civil nullity, it doesn't rise to the status of civil marriage. If anything creates a "lawful impediment" to a civil marriage, it would have to be a status that has the capacity to transform a civil marriage into a criminal act (for both the parties and, on the scope of the provisions, the celebrant as well).

This seems self-evident, but it is not. It is not when account is taken of how Canadian law has treated those in logically or practically indissoluble religious marriages. It is not self-evident when account is taken of the fact that Parliament exhausted its divorce jurisdiction with the Divorce Act. ${ }^{53}$ And it is not self-evident when s.290 of the Criminal Code is conjoined with the other bodies of Canadian law that regard religious marriages as nullities.

Starting with the language of the bigamy provisions, the section clearly distinguishes "marriage" from "forms of marriage". "Marriage" simpliciter is civil marriage. The use of the unqualified words "being married" in the first clause of the section (as distinct from "forms of marriage" in the second clause) implies that "being married" means being civilly married.

Once bestowed with the official status of civil marriage, the state does not permit that status to be muddied with any other marriage, whether civil or more informal in nature (i.e., formed under the auspices of nonstate law, either religious or community-affiliated). The prohibition applies to protect the status of a pre-existent civil marriage by prohibiting subsequent formal or informal marriages. This sequence, as we will see, is salient.

This argument about the clarity of civil status is indeed the standard way of understanding the mischief in bigamy, as opposed to

\footnotetext{
${ }^{52}$ Criminal Code, ss. 290;

${ }^{53}$ Under section 91:26, Constitution Act, 1867
} 
polygamy. Polygamy is intended to capture the state of affairs of having more than one spouse or being in a conjugal union with more than one person simultaneously. The bigamy provisions, on the other hand, speak to the offence of participating in a ceremony of marriage while already civilly married. ${ }^{54}$ A bigamous marriage is simultaneously a polygamous marriage while the reverse is not necessarily true. The distinct work of the bigamy provisions (relating to clarity of status) would be redundant without both the sequential dimension and without "marriage" simpliciter signifying civil marriage.

Beyond these arguments in statutory interpretation let me turn to the other ways that Canadian law has interpreted a "lawful impediment" to a civil marriage.

One of the most significant transformations in the Canadian understanding of a "lawful impediment" to a civil marriage derives from the Divorce Act of 1968 and the type of relationship that the state adopted with religious family law thereafter. As noted, Canada has always adopted a pluralistic law of marriage formation. Delegated religious officials can be authorized to perform civil marriages. We emphatically do not permit, however, any other means of dissolving a civil marriage than through the actions of a civil official - a judge. ${ }^{55}$

Just as Parliament did not occupy its jurisdiction to define marriage until the 2005 Civil Marriage Act, it did not occupy its legislative jurisdiction to create a national divorce regime until 1968. And with the Divorce Act, Parliament exhausted the field.

The Divorce Act consolidated a long-standing policy position of the Canadian government to the effect that we have one body of personal status law that applies to all Canadians equally (though religious officials can inaugurate entry into that status and religious law can informally coexist alongside it). Canada has never adopted something akin to a millet system of family law that assigns bodies of personal status law to distinct groups of citizens on the basis of religious, ethnic, or national affiliation.

\footnotetext{
${ }^{54}$ See Angela Campbell, "Bountiful Voices”, 2009 at 46, note 25; (unpublished article in author's possession)

${ }^{55}$ Section 7 of the Divorce Act: "The jurisdiction conferred on a court by this Act to grant a divorce shall be exercised only by a judge of the court without a jury." Divorce Act, R.S.C. 1985, c. 3 (2nd Supp.); hereinafter Divorce Act.
} 
The anomalous position of Catholics in Israel, for example, has no currency in Canada: Israeli Catholics cannot divorce civilly because the state provides no mechanism for civil marriage or divorce; and their body of religious law does not permit the dissolution of marriage through divorce.

Canada does not hive off separate communities, organized under principles of religious law or community law, who have no access to the same civil benefits and rights as other citizens. Canada's divorce legislation is, in this sense, universal. The universal jurisdiction of the Divorce Act has implications for civil bigamy and for the bigamy and polygamy provisions of the Criminal Code.

Very soon after the Divorce Act was enacted, Canadian courts had to deal with the legal consequences of the Divorce Act's universal jurisdiction. One of the earliest cases, Morris v. Morris, ${ }^{56}$ dealt with the scenario of Jewish agunot - women bound in Jewish marriages due to the fact that Talmudic law requires the husband to give his wife a bill of divorce and she to receive it, and particular husbands sometimes refuse to hand the bill to the wife. While the case refers to the predicament of civilly divorced Jewish women who remain religiously married, it also captures the predicament of civilly divorced Catholic spouses who remain indissolubly bound in a religious marriage.

One of the majority judges in the 1973 case of Morris, in arguing against the civil enforceability of religious marriages, speculates in the following manner:

Suppose...that a Catholic wife sought to resist her Catholic husband's petition for divorce on the ground that, having been married according to the Catholic faith, their marriage should be regarded as indissoluble. Such a plea would constitute a challenge to the authority of the court in divorce matters. It would represent an attempt to displace the general divorce law by the law of a particular religion. A plea of that kind would, of course, not be effective to prevent the court from applying the general law. ${ }^{57}$

${ }^{56}$ [1974] 2 W.W.R. 193, 14 R.F.L. 163, 42 D.L.R. (3d) 550; Hereinafter Morris.

${ }^{57}$ [1974] 2 W.W.R. 193, 14 R.F.L. 163, 42 D.L.R. (3d) 550; Hereinafter Morris. 
As an aspect of the "exclusive Legislative Authority of the Parliament of Canada [which] extends to...Marriage and Divorce"58 (italics added) bestowed by section 91 of the Constitution Act, 1867, the potentially conflicted co-existence of state and Catholic law is resolved by rendering the latter civilly ineffective, dwelling outside of the penumbra of "official" law. ${ }^{59}$

If Catholic family law (which prohibits divorce) were to retain its legal force vis a vis Canadian family law, the inevitable and unacceptable conclusion would be that the exclusive ability of the Canadian Parliament to create a single divorce regime for all Canadians would be compromised. The language of the 1968 Divorce Act, ${ }^{60}$ operative and cited by Mr. Justice Guy for the 1973 Morris case, was clear about the civil implications for religious law of a civil divorce: "Where a decree of divorce has been made absolute under this Act, either party to the former marriage may marry again."61

The clear implication of the scenario created by the 1968 Divorce Act is that a persisting religious marriage cannot be a "lawful" impediment to civil remarriage. It does not constitute a "prior existing marriage" for the purposes of provincial marriage solemnization acts.

This is reinforced throughout Canadian case law since divorce became an explicit, legislatively entrenched part of the national landscape in 1968. As it happens, the Jewish wife in the Morris case also happened

\footnotetext{
${ }^{58}$ Section 91.26, Constitution Act, 1867

59 This position underlines the case made out above that religious marriages are civil nullities.

${ }^{60}$ Divorce Act, R.S.C. 1970, c. D-8

${ }^{61}$ Section 16, Divorce Act, 1968.This language explicitly allowing all Canadian residents to remarry civilly after a civil divorce has been removed from the 1986 Divorce Act and replaced with similar phrasing, but not phrasing that so clearly articulates the universal and exclusive operation of state-based divorce law. The phrasing of the Divorce Act of 1986 is as follows: Section 13: "On taking effect, a divorce granted under this Act has legal effect throughout Canada." Section14: “On taking effect, a divorce granted under this Act dissolves the marriage of the spouses." Despite the difference in phrasing, the common law that has emerged around both Divorce Acts nevertheless cements this clear demarcation between "official” and "unofficial” law. Religious divorces or their absence remain unable to create or prevent the formation of a subsequent civil marriage.
} 
to have both divorced and remarried civilly according to "the perfunctory form prescribed for use by a Judge of the County Court"62 - despite a persisting Jewish marriage.

The meaning of a "lawful impediment" to civil marriage following the Divorce Act has implications for the criminal prohibitions on bigamy and polygamy.

The Catholic husband, in Justice Guy's example, is not made liable to polygamy and bigamy charges by re-marrying civilly while indissolubly married to another partner according to Catholic law. ${ }^{63}$ Otherwise, on Justice Guy's hypothetical above, the Catholic wife's challenge to the authority of the court in divorce matters - her attempt to displace the general divorce law by the law of a particular religion - would be effective. And Justice Guy is clear that her plea “of course” would not have that effect.

The state cannot create a unified and exclusive jurisdiction for divorce law that thereafter allows Catholics lawful access to civil remarriage upon their civil divorce and then turn around and prosecute them criminally for doing what they and every other citizen is permitted to do through a conjunction of federal divorce legislation and provincial marriage solemnization legislation.

The logical implication of the situation that exists after 1968 is that Canada tolerates "informal" bigamy; ${ }^{64}$ tolerates the simultaneous existence of a civil marriage to one party and a religious marriage to another, particularly in the case that the civil marriage follows the religious marriage.

The further clear implication of the post-1968 Divorce Act situation is that when the Criminal Code prohibits "any form of polygamy" 65 , an exception to this rule has been jurisprudentially carved

62 Ontario's “perfunctory form” of marriage solemnization is outlined at s.24 (1)-(2) which allows a judge or justice of the peace to perform the act between the hours of 9 o'clock in the morning and 5 o'clock in the afternoon.

${ }^{63}$ Can. 1141: A marriage which is ratified and consummated cannot be dissolved by any human power or by any cause other than death. Codex Canonici, 1983.

${ }^{64}$ i.e., where the second marriage is a non-state based marriage such as religious marriage

${ }^{65}$ under part (1)(i) of section 293 
out for at least Jews and Catholics. Any intuitive clarity that might have been attributed to that phrase is significantly compromised by the ability of Jewish and Catholic marriages to one party to persist alongside civil marriages to other parties.

Just as "any form of polygamy" is rendered precarious by this state of affairs the phrase "any conjugal union, whether or not it is recognized as a binding form of marriage” is rendered ambiguous. Aren't Jewish and Catholic marriages forms of conjugal union? What on earth can this phrase mean if those two forms of marriage do not qualify?

On one reading of these implications, religious marriages en masse are neither "forms of marriage", nor "conjugal unions" under the bigamy and polygamy provisions. And the bigamy provision prohibits two civil marriages to separate partners, not a civil marriage to one followed by a religious marriage to another. This latter reading is consistent with the case law relating to the Divorce Act and the meaning of "lawful impediment" in provincial marriage (solemnization) acts. It makes intuitive sense to treat all religious marriages the same way, whether or not they precede or follow a civil marriage. This reading is consistent with the civil nullity of religious marriages discussed above. And it is consistent with Canada's tolerance of plural religious unions, both de facto and in private international law. For both civil and criminal purposes, a plurality of nullities is a nullity.

But the case law may also be consistent with the (surely bizarre) conclusion that a religious marriage to one person while civilly married to another is legal so long as the religious marriage precedes the civil marriage. If the civil marriage comes first, the sequential criteria in the bigamy provisions appears to kick in.

It is hard to justify a sequential distinction between a prior religious marriage to one party followed by a legitimate civil marriage to another and the civil marriage to one partner followed by an illegitimate (criminally prohibited) religious marriage to another. If the policy justification of the bigamy provision is to ensure that the status of civil marriage is not muddied by the simultaneous existence of two forms of marriage, then surely there is no difference between the two scenarios. They both confound the civil consequences of civil marriage; both leave uncertain how property accumulated over the course of the relationship is to be divided; both leave unclear whether separate spouses are entitled to spousal support and by what proportions; both leave unclear which spouse 
can claim third party benefits such as standing in wrongful death suits or immigration sponsorship.

In fact we don't need to be so specific about what kinds of informal marriage (religious for example) muddy the waters of civil marriage. The simple coexistence of a relationship of unmarried cohabitation to one person alongside an ongoing civil marriage to another muddies the civil consequences of the civil marriage. As we will see below, the jurisprudence on the polygamy offence appears to allow for this scenario: Long-term conjugal cohabitation with one person (with or without children) is legally consistent with monogamous civil marriage to another. ${ }^{66}$ The polygamy case law (such as it exists) appears to have carved this common law exception out of the ambit of "any form of polygamy" or "any kind of conjugal union".

Surprising as is this latter exception to polygamy, at this point I want to underline that it too confirms that the policy justification for singling out arrangements in which a person marries someone religiously while already civilly married to another (as per the strict sequence specified in the bigamy provisions) are no longer coherent. The status of a civil marriage is muddied as soon as it can legally co-exist with religious marriage to, and spousal cohabitation with, another party.

\section{RELIGIOUS DISCRIMINATION}

Beyond the policy incoherence of the current bigamy provisions, there is also a potentially discriminatory nature to an interpretation that allows an exception for some religious groups and not others.

Canadian law has already accommodated the particularities of Jewish and Catholic family law by ensuring neither group will suffer the indignity of criminal prosecution due to the interaction of civil divorce law and criminal bigamy law.

Leaving aside the conjugal content of the unions (content to which I will return below), the state clearly allows plural marriages to exist for Catholics and Jews (a persisting religious marriage with a new civil marriage to a separate partner), it is hard to see why other types of plural

\footnotetext{
${ }^{66}$ See the discussion about the Tolhurst case below.
} 
marriage deriving from the combination of religious and civil law are not uniformly acceptable. Once provincial marriage (solemnization) acts become indifferent to some cases of two "forms of marriage" to different spouses (civil and religious if the religion is Jewish or Catholic), they have no principled way of distinguishing between any combination of a single civil marriage to one person combined with a religious marriage to another.

The polygamy provision speaks to "any form of polygamy" and "any kind of conjugal union" to more than one person at a time. But clearly, when we use these words, they don't have a plain meaning. Jews and Catholics can have plural marriages (civil + religious) and they will not be captured by either of the phrases in the polygamy provision. The polygamy provisions have to be read in such a way that Jewish and Catholic marriages are not of themselves conjugal unions and do not create forms of polygamy when conjoined with separate civil marriages. Or, put another way, it is the factual conjugal content of religious marriage that creates potential jeopardy. The marriage itself neither constitutes nor substitutes for that content. This leaves us, once again, with conjugality as the defining feature of polygamy.

Any language of this new rule that singles out Jews and Catholics would create an unacceptable distinction. A religion-neutral formulation would have to be formulated such that an exception for all religious marriages has been carved out of "any kind of polygamy" and "conjugal union”.

This religion-neutral interpretation of both the bigamy and polygamy provisions would put all religious marriage law on the same footing as Jewish and Catholic law - a policy objective that surely competes with the already compromised one of ensuring the status of civil marriage remains unmuddied. This interpretation would also be consistent with the rest of Canadian law that regards religious marriages as nullities. And it would be consistent with the Civil Marriage Act that defines marriage only for civil purposes. For the purposes of the latter, bigamy can continue to be read as prohibiting everyone, being civilly married, from going through another civil marriage with another person. As I will argue below, there may be compelling policy reasons for the Canadian state to uphold this monogamous understanding of civil marriage.

At this juncture, it might still seem possible to generate a religionneutral formulation of the polygamy provision such that the rule allows for civil marriage plus religious marriage to separate parties but only where 
[VOL. 05 No. 01

the internal rules of the religious marriage do not permit plural marriages. Catholics and Jews would be safe on this very shaky new foundation; Muslims and Fundamentalist Mormons would not.

Apart from the very thinly veiled reassertion of a distinction that constitutes forbidden religious discrimination, this new definition would not work either. Catholics and Jews, civilly married to one spouse and religiously to another, are now legally free to share a residence with all of their marriage partners, to engage in sexual activity between and amongst the three of them, to share domestic tasks and pool assets, to raise the children of each marriage as one big new blended family - in short they are legally free to engage with themselves and the world as a plural family unit.

On its own - without reference to conjugality - this configuration would not be considered "any form of polygamy" nor is there more than one "conjugal union" in play simply by virtue of the conjunction of a religious and civil marriage to distinct partners. The state has already affirmed, through the Divorce Act's universal jurisdiction in interaction with the interpretation of "lawful impediments" to civil marriage, that all of this activity associated with religious marriage is consistent with monogamy. The state has already legally permitted this arrangement to flourish.

Of course I have launched this scenario from a wholly secular set of assumptions about the choices that individuals are free to make with their civil liberties. The religion of each of these parties might have something altogether different to say about the hypothetical arrangement.

But the state cannot have any concern about whether Judaism and Catholicism would approve of this arrangement. The government cannot draw on the internal institutions and beliefs of each religion to shore up whatever disapproval it might feel because this would invite religious doctrine into the deliberations of state. Beyond engaging in the legislative and judicial review of spiritual doctrine, which a long line of Canadian jurisprudence prohibits, ${ }^{67}$ this review would have to unfold in a particularly discriminatory way, privileging the worldviews of some religious communities over others to bend the ear of state.

\footnotetext{
${ }^{67}$ See Lakeside Colony of Hutterian Brethren v. Hofer, [1992] 3 S.C.R. and 165 Bruker
} v. Marcovitz, 2007 SCC 54 
The ribald scenario that I laid out above hints at an understanding of "conjugal union" or "spouse-like relationship" that flirts with the mischief that many people struggle to articulate as the real mischief in polygamy - i.e., that we are not concerned with the formal rules of religious law alongside the formal rules regarding what constitutes a civil marriage. We are really concerned about the behaviors that go on within those formal arrangements.

I will return to what those worrisome behaviors might be when I turn later to an analysis of the phrase "conjugal union". For now, I just want to underline that the plural unions that the state theoretically allows to legally flourish for Jews and Catholics look almost totally indistinguishable from what could go on within the plural unions of those religious groups whose internal rules permit plural unions. By allowing the plural unions of Jews and Catholics, the state has lost all principled (and constitutional) ways of distinguishing between different bodies of religious thought on the question of plural unions. The more principled reading of the Offences Against Conjugal Rights is that an exception has been carved out of the provisions such that all religious marriages are civil and criminal nullities; are of-themselves neither "forms of marriage", nor "conjugal unions", nor capable of generating "any form of polygamy" unless conjoined with conjugality.

In light of the variety of ways that plural religious unions are in fact permitted in Canadian law - are not regarded as "forms of polygamy" or "any kind of conjugal union with more than one person at the same time" - what exactly is the residual harm that is left in these criminal provisions? We have already seen how, following Lamer's injunction to apply the void for vagueness doctrine to judicial decisions beyond the bare words of a statutory provision, that family law over the last 40 years has in many ways eviscerated bigamy and polygamy of meaning. What further sense can be made of the polygamy provisions?

The next section struggles (mightily) to articulate the specifically criminal mischief (as articulated in criminal law jurisprudence) that these Criminal Code provisions are aiming to circumvent - a mischief that attracts a very significant penalty of up to five years imprisonment. 
[VoL. 05 No. 01

\section{CUSTOMARY MARRIAGE, ADULTERY, AND UNMARRIED COHABITATION}

In light of both legal and sociological developments that have emerged since the polygamy and bigamy provisions entered into the first Canadian Criminal Code in 1892, the secular standard for what constitutes this particular crime has become exceedingly difficult to articulate. This difficulty arises out of the construal of religious marriages as nullities and the interaction between the Divorce Act, religious law and the Criminal Code's Offences Against Conjugal Rights.

The difficulty in pinpointing the secular mischief in polygamy also arises from the extraordinarily small number of cases ever prosecuted under the provision since their inception, most particularly one involving an Aboriginal man, the other an "adulterous relationship". ${ }^{68}$ It is to the specifically criminal law interpretation of the provisions that I will now turn.

Since the Criminal Code provisions were drafted in 1892, there have only been a handful of prosecutions under the polygamy sections. One of the more salient ones from amongst this handful was the 1899 case of a Blood Indian from the North West Territories, Bear's Shin Bone, who was convicted under the section for having entered into simultaneous conjugal unions with two women. ${ }^{69}$ The marriages were formed "Indian

\footnotetext{
${ }^{68}$ I will be focusing principally on the Bear's Shin Bone case from 1899 and the Tolhurst and Wright decisions from 1937 as both of these together, read in conjunction with family law developments since the 1968 Divorce Act, amply show the incoherence of the polygamy provisions. See $R$. v Bear's Shin Bone, 1899 CarswellNWT 32; hereinafter Bear's Shin Bone and R. v. Tolhurst; R. v. Wright, [1937] 3 D.L.R 808 (Ont. C.A.); hereinafter Tolhurst. For others of the scattered (and generally cursory, if not unreported) polygamy and bigamy cases, see $R$. v. Nan-E-Quis-A-Ka, 1889 CarswellNWT 14; hereinafter Nan-E-Quis-A-Ka; $R$ v. Labrie (1891), 7 M.L.R. QB. 211 (Que. C.A.); R. v. Liston (1893) (Toronto Assizes, unreported) as mentioned in Raney, W.E. 1898 "Bigamy and Divorce" Canadian Law Journal, 34: 546; The King v. John Harris (1906) 11 C.C.C. 254 (Que.); Dionne v. Pepin (1934), 72 C.S. 393, 40 R. de Jur. 443 (Que. S.C.); See R. v. Clarke (1959), 124 C.C.C. 284 (Man. C.A.); R. v. Moore (2001), WL 596386 (Ont. Ct. J.); R. v. Moustafa, [1991] O.J. No. 835 (Ont. Ct. J. (Prov. Div.)); R. v. Sauvé, [1997] A.J. No. 525 (Alta. Prov. Ct.); R. v. Young, [1965] O.J. No. 498 (Ont. C.A.).

${ }^{69}$ R. v Bear's Shin Bone, 1899 CarswellNWT 32; hereinafter Bear's Shin Bone
} 
fashion”, meaning "he promised to keep her all her life, and she promised to stay with him, and that that was the way Indians got married.,"70

The analysis of what constitutes an "Indian marriage" in the NanE-Quis-A-Ka case, upon which the judgment in Bear's Shin's Bone relies, is articulated in a manner that may be ethnocentric and offensive to internal Aboriginal understandings of customary marriage. However it is worth reproducing for its resonance with the contemporary widespread phenomenon of cohabitation. The judge in Nan-E-Quis-A-Ka relies on the following conception of "Indian marriage":

It is plain that among the savage tribes on this continent marriage is merely a natural contract and that neither law, custom nor religion has affixed to it any conditions or limitations or forms other than what nature has itself prescribed....Wherever marriage is governed by no statute consent constitutes marriage and that consent is shewn by their living together. ${ }^{71}$

It is hard to suppress the realization that the "marriage" for which the Bear's Shin Bone judge was convicting is functionally closely commensurate with contemporary statutory understandings of unmarried cohabitation.

But Aboriginal customary marriage is not quite commensurate with cohabitation as it lacks the requirement (now set out in federal and provincial statutes) for a qualifying period of living together (generally 1-3 years), made shorter by the birth of a child. ${ }^{72}$ An Aboriginal customary marriage is broader and more easily formed than unmarried cohabitation something that appears to make Aboriginals more prey to conviction under the polygamy law.

Indeed for the case of Aboriginal customary marriage, the jurisprudential understanding of "form of marriage" or "conjugal union"

\footnotetext{
${ }^{70} \mathrm{R}$ v. Bear's Shin Bone adopts the criteria for “Indian Marriage” set out in Nan-E-QuisA-Ka

${ }^{71}$ Nan-E-Quis-A-Ka at paras 3 and 6

72 For example, see the definition of spouse laid out in section 29 of Ontario's Family Law Act
} 
appears to be fairly broad for conviction - but only, as we will see, for an Aboriginal convict. For Aboriginal people alone consent constitutes marriage and living together constitutes consent; the prescriptive periods simply fall away. Theoretically, like the spouse-in-the-house rules for women on social assistance, ${ }^{73}$ an Aboriginal customary marriage can form after a relatively brief period of "living together".

The pre-1573 ecclesiastical requirements for a valid clandestine marriage are not even present for Aboriginal people; the former required both consent and consummation. ${ }^{74}$ For Aboriginal customary marriage, consent is presumed from nothing more than a state of fact (living together for an indeterminate length of time) and consummation is dispensed with altogether as a requirement of validity.

How is it that Aboriginal people have a distinct regime for marriage formation - and one that seems to leave them spectacularly open to prosecution under the polygamy provisions?

The contemporary legal way to distinguish Aboriginal and nonAboriginal cohabitation is via section 24 of the 1867 Constitution Act and section 35 of the 1982 Constitution Act. The former facilitates the creation of a distinct marriage regime for Aboriginal people under the auspices of federal jurisdiction and the latter constitutionally protects persisting Aboriginal rights from extinguishment and encroachment. What might otherwise be functionally analogous to unmarried cohabitation (living together constitutes consent and consent constitutes marriage) can be thereby elevated for Aboriginal people to the constitutionally protected status of a "customary marriage”.

\footnotetext{
${ }^{73}$ Under the Harris Government in Ontario, a spouse-like relationship was generated for opposite sex couples if they merely shared a common residence, a definition that resulted in 10,013 people being cut off social assistance, $89 \%$ of whom were women and $76 \%$ of whom were single mothers. The regulations have now been modified in response to the constitutional challenge of the Falkiner et al v. Director, Income Maintenance Branch, Ministry of Community and Social Services and Attorney General of Ontario, 2002 CanLII 44902 (On. C.A). However the modification now creates a spouse-like relationship after a mere 3 months, long before spousal support could be claimed in lieu of social assistance. See Janet Mosher, Welfare Fraud and the Constitution of Social Assistance as Crime, (principal investigator and primary author) with Professor Joe Hermer (Ottawa: Law Commission of Canada, 2005) at 24-25.

${ }^{74}$ See Gaudemet, supra, note 47.
} 
This constitutional security perversely appears to expose Aboriginal people to a particular type of vulnerability under the Criminal Code's Offences Against Conjugal Rights. Aboriginal Canadians appear to have been uniquely exposed to conviction for polygamy - a cautionary tale about the availability of these deeply ambiguous provisions to “discipline” socially and politically marginal groups in Canada.

The extraordinarily broad interpretation of "conjugal union" in Bear's Shin Bone needs to be squared with one of the other cases from the handful of instances where the polygamy provisions were prosecuted, a 1937 pair of adultery cases: $R$ v. Tolhurst and $R$. v. Wright. As these cases make up the rest of the sparse recorded case law on the polygamy section, we are compelled to turn to their antiquated parameters to decipher the internal logic of the offence over the first century of its presence in the criminal law. The striking lack of coincidence between the polygamy jurisprudence and contemporary legal understandings of the family underline how much dust has settled on this unused section of the Criminal Code.

In the Tolhurst and Wright cases, James Tolhurst was civilly married to one woman and committed adultery with May Wright, who also happened to be civilly married to another man. Both James and May were prosecuted for polygamy given that they were apparently both in multiple simultaneous conjugal unions with another wife and husband respectively.

The judge in this case, in ruling out a conviction, determined that an adulterous relationship is not a "conjugal union”. Conjugal unions are only created if they are "in the guise of marriage". If they are not "in the guise of marriage", they are simply unions. Adultery is consistent, in other words, with monogamy.

Conjoining Bear's Shin Bone, Nan-E-Quis-A-Ka, and Tolhurst to struggle towards a principled secular definition of polygamy under the Criminal Code, it appears that the rule might be that a prohibited conjugal union arises if one is not simultaneously civilly married (Nan-E-Quis-A$\mathrm{Ka}$ and Bear's Shin Bone); but cohabitation does not rise to a conjugal union if one is civilly married to someone else (Tolhurst).

This attempt to get at what exactly is proscribed in the Criminal Code is undermined by another Aboriginal case from 1867: Connolly v. Woolrich. ${ }^{75}$ In that case, a judge from a Quebec court (in what was then

75 (1867) 11 Lower Can. Jur. 197; hereinafter Connolly. 
Lower Canada) "held the marriage of [a] white man with [a] Indian woman ... contracted according to Indian custom to be a good valid and legal marriage, although the husband and wife had removed to Lower Canada and the husband had afterwards there married a white woman according to the rites of the Roman Catholic Church."76 In Connolly, an Aboriginal customary marriage was considered a valid civil marriage; indeed the case turned on the civil consequences of two potentially valid marriages in law for the purposes of a will.

So, between the polygamy cases of Bear's Shin Bone and Tolhurst (some of the polygamy section's very few reported decisions) the above attempt at a principled rule cannot be sustained. The only relevant difference between Bear's Shin Bone and Tolhurst is the Aboriginality of the first defendant.

It might appear that the mischief in the polygamy provisions is a party sustaining not only a civil marriage, but also a simultaneous longterm "marriage-like" relationship. In other words, one might suggest that Tolhurst stands for the proposition that a brief sexual fling with one party, while civilly married to another, is not going to attract the concern of the polygamy provisions, but living together as "husband and wife" (as Bear's Shin Bone did) with two different women at the same time is. The real mischief, on this thesis, is maintaining a home with one spouse, inside which the parties have a conjugal life, while civilly married to another.

This suggestion for a principled civil definition of polygamy can't stand on the very facts of Tolhurst. He not only lived with May Wright "as man and wife" (to cite the language of the case), they had four children together. They might have been committing mere adultery vis a vis their civil marriages, but their relationship could not fit more squarely within the current definition of common law spouse (in all provincial and federal statutory definitions of common law spouse). In Ontario, that definition is construed as follows: cohabiting together in a conjugal relationship for a period of not less than three years or in a relationship of some permanence if both are the parents of a child. ${ }^{77}$ As May Wright bore a minimum of four children which she raised with James Tolhurst, she and Tolhurst were not only in a relationship of some permanence with a child, they surpassed

\footnotetext{
${ }^{76}$ Cited in Nan-E-Quis-A-Ka at para 8

${ }^{77}$ Section 29, Family Law Act.
} 
Ontario's criteria for childless couples when the four 9 month pregnancies are added up (leave aside any associated years of child-rearing). They alone come to 36 months (i.e., three years).

According to the very facts of Tolhurst and the logic that ensues from those facts, statutory unmarried cohabitation is not "in the guise of marriage", nor are they "conjugal unions" nor are they "any form of polygamy" for the purposes of the polygamy provisions. Long term unmarried cohabitation to one spouse, with or without children, are therefore consistent with monogamy to another. Living in unmarried cohabitation while civilly married to another does not constitute polygamy.

A fortiori, if simultaneous unmarried cohabitation and civil marriage to different people do not court the polygamy provisions, two simultaneous cohabitational relationships will not either. Unmarried cohabitation does not create conjugal unions "in the guise of marriage". For the purposes of the bigamy and polygamy provisions, both religious marriages and unmarried cohabitation are nullities and a plurality of them will amount to a nullity. In addition to Canada's tolerance of plural religious marriages, Canadian law tolerates plural unmarried cohabitation. This appears to be the inexorable logic of the extant criminal case law on the polygamy offence.

The criminal law judgments of Tolhurst and Wright are clearly out of step with contemporary legal understandings of unmarried cohabitational relationships. Where the judge in Tolhurst saw no marriagelike relationship in an enduring adulterous one, even the Criminal Code now defines "common-law partners" as those who cohabit in a conjugal relationship for a period of at least one year. ${ }^{78}$ The emphasis on formal conjugality in the Ontario Court of Appeal in 1937 has now been almost completely turned on its head such that the formal conjugality of civil or religious marriage is irrelevant in law and the functional conjugality of the union is the locus to which courts must turn to suss out the mischief of polygamy. Again, conjugality bears the full weight of the offence of polygamy - a weight it is itself too precariously perched to support.

Before getting closer to functional content of conjugality, it is worth examining how Canadian law has treated Aboriginal customary marriage outside of the polygamy provisions as this treatment advances

${ }^{78}$ Criminal Code, R.S.C. 1985, c. C-46 at section 2. 
my argument about the discriminatory potential in the polygamy provisions. For the purposes of the Criminal Code, the only way to distinguish the functionally indistinguishable institution of unmarried cohabitation from Bear's Shin Bone's “Indian marriage” is to recognize a distinct regime for Aboriginal people. Section 35 of the Constitution Ac, 1982 constitutionally protects the latter to the extent that federal law has not extinguished Aboriginal customary marriage. The 1995 case of Manychief v. Poffenroth confirms that the federal government has not done so. ${ }^{79}$

Manychief is a case where an Aboriginal woman sought to bring a wrongful death tort claim under the Fatal Accidents Act as a customary wife, a right that the statute denied her as a common law wife. The Fatal Accidents Act, while now amended, excluded common law spouses from the right to bring a wrongful death claim at the time of pleadings. Only married spouses were eligible. The claimant argued that her Aboriginal customary marriage rendered her a "married" spouse. Perversely, the Manychief decision recognized "Marriage by Indian Custom" as a protected Aboriginal right under section 35 of the Constitution Ac, 1982; it further confirmed that the claimant would indeed be entitled to bring a claim under the Fatal Accident Act if she were "married by Indian custom"; ... however the judge denied the claim deeming the claimant to have been living in a mere common law relationship, not a customary marriage.

Rather appallingly, while being Aboriginal was sufficient to render Bear's Shin Bone's common law relationship into a "customary marriage" for the purposes of polygamy (Tohurst and May being spared that fate for want of the "guise of marriage"), Delia May Manychief's Aboriginality was insufficient to render her common law relationship into a "customary marriage" for purposes that might be of benefit to her. The "mere" common law relationship of one Aboriginal person is not enough to entitle her to statutory rights under provincial legislation but is enough, it appears, to convict another Aboriginal person of polygamy under federal law. This is a further caution to add to the cautionary tale of Bear's Shin Bone.

\footnotetext{
79 [1995] 2 C.N.L.R 67 (Alberta Q.B.); hereinafter Manychief
} 


\section{SEXUAL MISCHIEF}

On the basis of the thin and antiquated reasoning of Canada's reported polygamy cases, adulterous and long term common law relationships with one party are not "forms of polygamy" nor "conjugal unions with more than one person" when conjoined with civil marriage or cohabitation to another person (unless one is an Aboriginal person). Perhaps there is some other way to preserve the early $20^{\text {th }}$ century emphasis on formal conjugality while still getting at some other discrete mischief with which it might interact to generate the grave social harm of polygamy. This might prevent the complete collapse of the offence into functional conjugality - a legal construct that will require considerable solidity to support the freight that it would have to carry.

If it is not the "living together" with one woman while civilly married to another that is problematic, it might appear that the mischief in the polygamy provisions is aimed at the prospect of a party having ongoing simultaneous sexual congress with one party while civilly married to another. If James Tolhurst were having sex with his civil wife at the same time as he was having regular sex with his common law wife then perhaps that would be the problematic behaviour. But that cannot be the mischief:

There can be no prohibition on having sex with one's civil wife (except for the criminal law requirement that she be consenting). Consensual sex with one's wife does not become problematic even if a husband is simultaneously committing adultery with another woman; and the judgment in Tolhurst explicitly indicates that an adulterous relationship (which of its nature includes sex) is consistent with monogamy; so sex with a common law spouse does not become problematic just because one is also having sex with one's civil spouse. This interpretation squares with the scenario laid out above that a party in an indissoluble religious marriage to one party and a civil marriage to another can engage in sexual relations with both without courting the polygamy provision.

That sex with one partner, while civilly married in a sexually active relationship to another, does not constitute polygamy is confirmed in a more recent string of cases that deal with the legality of polyamory. In a 1982 case, an Ontario court held that swinging, or spouse-swapping parties, in a private non-commercial setting does not constitute an indecent 
act for the purposes of the Criminal Code. ${ }^{80}$ Husbands and wives (common law and civilly married) can freely invite other sexual partners into their homes for the pleasure of either or both.

The acceptability of home-based swinging to prevailing community standards was complimented at the Supreme Court by the acceptability of swinging in bars. In the 2005 case of $R$. v. Labaye $e^{81}$ the accused operated a club in Montréal the purpose of which was to permit couples (married or not) and single people to meet each other for group sex. He was charged with keeping a common bawdy-house under s. 210(1) of the Criminal Code.

The question of whether swinging is consistent with polygamy has not been tested directly by the polyamory cases. But the fact that the Supreme Court of Canada has found that swinging in private homes and clubs does not rise to a criminal act speaks to whatever mischief can be discerned in the polygamy provisions.

The offence of keeping a "common bawdy-house" is itself defined by reference to the slippery concept of "indecency". 82 The central issue was whether running a club for group sex and the swapping of partners constituted the facilitation of acts of indecency. Setting a threshold for indecency, then, became the fulcrum of the case; and the concept of "harm" is at the centre of mischief of indecency.

In acquitting the accused, the Supreme Court of Canada made clear that the Crown failed to establish that any harm had been committed, a threshold set by determining whether the conduct confronts the public with behavior that interferes with their autonomy and liberty, pre-disposes others to anti-social behavior, or physically or psychologically harms the people involved in the conduct. The harm also needs to be incompatible with the proper functioning of society.

In the case of swinging, insofar as the activity was taking place in a private setting, the threshold of harm was not met. The privacy behind which group sex was veiled eliminated potential harm to the liberty rights of other citizens through confrontation. It also eliminated fears about the

\footnotetext{
${ }^{80} R$ v. Mason [1982] 59 C.C.C. (2d) 461

${ }^{81}$ [2005] 3 S.C.R. 728; hereinafter Labaye.

${ }^{82}$ See sections 210(1) and 197(1) of the Criminal Code.
} 
fostering of anti-social behavior in others, which "can arise only if members of the public may be exposed to the conduct or material in question."83

On the question of whether swinging is incompatible with the proper functioning of society, the court also invoked the privacy of the behavior to inoculate the activity from posing a risk of harm to society's proper functioning. The court is further clear that "[v]ague generalizations that the sexual conduct at issue will lead to attitudinal changes and hence anti-social behavior will not suffice." ${ }^{84}$ Mr. Labaye was not guilty of indecency because of the actions he took to make sure only willing people would see the sexual conduct.

The facts of the Labaye case speak to types of plural sexual partnering (simultaneous) that are generally not the practice within polygamous unions. A fortiori the judgment indicates that whatever sexual activity takes places between consenting adults within polygamous unions also fails to meet the threshold of harm requisite for indecency, most particularly because polygamous unions, like marriages in general, conduct their erotic lives in private. Further (recapitulating the court's assessment of harm in the context of polygamy) "vague generalizations" that polygamy "will lead to attitudinal changes and hence anti-social behavior will not suffice" to establish harm of polygamy.

The Labaye case appears to speak definitively to any conjecture that the secular mischief in polygamy is related to indecent sexual acts. Multiple simultaneous sexual partners (married or otherwise) are not indecent in criminal law; multiple sequential partners (married or not) within plural unions then fall substantially short of the threshold of harm. The polyamory cases go some distance to further eviscerating the content of the polygamy provisions. The result in Labaye stands for the proposition that sexual activity in general within polygamous unions is not the targeted harm. Consensual sexual activity between adults is covered by privacy.

\footnotetext{
${ }^{83}$ Labaye at para 47

${ }^{84}$ Ibid, at para 58
} 
[VOL. 05 No. 01

\section{SHARED RESIDENCE}

If we take seriously the extant jurisprudence on polygamy, we can conclude from the judgment in Tolhurst that either party having sex with a third party to a civil marriage (adultery) is congruent with monogamy. We have seen from the facts regarding the "affair" in Tolhurst that a long-term adulterous relationship while civilly married to another is consistent with monogamy. Given that the statutory definition of cohabiting spouse now covers the facts of Tolhurst like a blanket, (he was living with for a period exceeding three years and had four children with her) we know that unmarried cohabitation to one partner while civilly married to another is consistent with monogamy. Neither swinging, nor an adulterous fling, nor an adulterous affair, nor unmarried cohabitation are conjugal unions "in the guise of marriage" for the purposes of the criminal law offences of polygamy and bigamy.

Does the cohabitational relationship have to be taking place in the same house as a civil marriage to constitute polygamy? Does the difficulty come with installing a second (fourth, seventh...) sexual partner in the same home? I.e., with the prospect that several parties in these unions decide to live with each other's existence; or, further, live with each other and the third?

Incidentally, if installing a second sexual partner in the same home were the criterion used to suss out the secular mischief in polygamy, then polygamy would be allowed so long as each wife had a separate living residence. The vociferous crowd rallying for prosecutions of fundamentalist Mormon marriages might not be so comfortable with this distinction. Those mostly like to be able to afford to install plural wives in separate residences are likely to be the religious and community leaders who are the prime targets of prosecution. ${ }^{85}$

The idea that multiple sexual partners installed in the same residence is the mischief also leaves a peculiar loophole for the "Big Love" scenario in which each of the three wives has a separate house, each

\footnotetext{
${ }^{85}$ Reports are starting to emerge out of Bountiful that some of the plural celestial unions take place with multiple sister wives having their own residences. See Campbell, supra, note 34
}

“Bountiful Voices”, 2009 at 46, note 25; (unpublished article in author’s possession) 
house being joined to the next through a series of doors. ${ }^{86}$

And if "Big Love" meets the criteria of separate residences for each wife, then why doesn't three separate bedrooms with a shared kitchen and bathroom, or three separate beds in the same room separated by curtains, or three separate places in the bed separated by blankets (the next step belonging to both erotic and metaphysical realms of separation and intermingling)?

Leaving aside all of the semantic difficulties in identifying the mischief with multiple sexual partners installed in the same residence, the criteria is offered because the mischief appears to be having more than one spouse at the same time. Living in the same residence is just a short hand way of identifying when the problem with more than one partner at the same time gets criminally uncomfortable. Clearly swinging with more than one partner is not the problem. But when the relationship with each sexual partner becomes spouse-like, it's at that point that the mischief in polygamy is activated. The reference to a shared residence is just one way of getting at what is spouse-like. If we can concentrate on multiple spouselike relationships, it seems that we would be able to capture those polygamists who can afford to set their wives up in separate residences as well as those who dwell together in the same home.

This identification of the mischief gets us close to the second part of section 293: "conjugal unions" - the only part of the section that appears to remain standing once all of the other exceptions to polygamy have been carved out of by the substratum of values that has churned up legal landscape over the last half century. Perhaps it seems viable that multiple "conjugal unions" (another word for "spouse-like relations") might have a purchase in this exercise; in other words it seems that the original drafters of the polygamy provisions nailed it when they referenced polygamy to conjugality.

It remains to be seen whether this last (really the very last viable) understanding of the mischief in polygamy can hold any water. What do we mean by a “conjugal union”. Once we've figured that out, then more than one of those type of union at the same time with separate people will presumably be the behavior that criminal law forbids.

86 "Big Love" is an HBO television series that depicts a polygamous fundamentalist Mormon family composed of three wives, one husband, and their multiple children, living in suburban Utah. 
This search for a definition of “conjugal union” takes us away from the criminal law, which does not itself define what constitutes the relationship. To get a clear sense of what is meant by conjugality, we need to return to family law, which has spent the last 40 years trying to clarify the term since the Divorce Act opened up a revolution in the way the official family is legally structured and sociologically conceived. It is in family law that both statutes and cases have struggled to fulfill Lamer's task of clarifying open-ended statutory language through judicial interpretation.

\section{CONJUGAL UNIONS}

Leave aside for a moment the unquestioned assumption that we have good reason to care so much that a swinging partner stays in the bed a bit too long and whips up a batch of French toast a few times too many. Leave aside the unquestioned assumption that we have good reason to care even if none of the parties themselves seem to mind. In other words, leave aside the search for a principled policy justification for whatever residual understanding of conjugality is left in the Offences Against Conjugal Rights once swinging, adultery, religious marriage and (on the polygamy section's jurisprudence) even unmarried cohabitation are taken out. The definition of "conjugal union” has enough difficulty on its own.

To determine that, while within one spouse-like relationship, one was simultaneously within a second spouse-like relationship, we would first need to determine what it is to be spouse-like; i.e., determine exactly what makes a spouse a spouse. If we had a clear sense of the concept of spouse (that which is at the essence of the married relationship) then we could determine that someone had multiple simultaneous spouses whether or not they were in a common law, religious, or civil marriage.

Identifying what the essence of the marriage relationship is for the purposes of determining what is marriage-like in the absence of the actual solemnization ceremony has proven to be an increasingly elusive quest. The institution of marriage itself now contains such an extensive array of variants (with or without children, living in the same residence or not, with or without sexual activity, with traditional, equal, or reverse-traditional gender roles...) that it is difficult to identify more than patterns across a range of marriages, rather than a set of essential criteria. Furthermore, the 
frequency of committed relationships flourishing outside of civil marriage is increasing, with the result that the law has been restructured to attach similar legal consequence to both married and unmarried relationships. ${ }^{87}$

The growing frequency with which couples decline to enter a civil marriage while persisting in committed relationships led to a significant overhaul of both federal and provincial legislation to accommodate the last half century's sociological shift. This reform became most pressing when it coincided with a sequence of successful gay rights cases that saw governments ungraciously scrambling to recognize same sex spouses without changing the definition of marriage. This statutory overhaul of the concept of spouse was stimulated by a series of Supreme Court cases in the last decade of the $20^{\text {th }}$ century that ruled that discrimination on the basis of either marital status or sexual orientation created unconstitutional violations of the right to equal treatment under the law. Two cases in particular, Miron v. Trudel and $M$. v. $H^{88}$ led to a massive overhaul of the legislative landscape whereby 67 federal statutes and numerous provincial statutes were amended to ensure that unmarried cohabitants, whether in same-sex or opposite-sex relationships, would have the same rights as married spouses in both fields of legislative activity. As a result, legislation dealing with matters from tax deductions to pensions, death benefits to intestate inheritance, standing in wrongful death suits to immigration sponsorship, draws upon the concept of a "conjugal union” to create demarcations between those who qualify under the legislation and those who do not.

The statutory definition of a cohabiting spouse typically stipulates a specific period of cohabitation after which legal consequence ensue, generally ranging from one to three years, depending on the statute. This statutorily set period of cohabitation substitutes for the single event of a solemnization ceremony for entry into unmarried cohabitation out of

${ }^{87}$ The 2007 report of Statistics Canada on changing family demographics indicates that between 2001 and 2006, the number of cohabiting families grew by 18.9\%, five times faster than married couples, to form $15.5 \%$ of census families. See Statistics Canada, "Family Portrait: Continuity and Change in Canadian Families and Households in 2006, 2006 Census”, by Anne Milan, Mireille Vézina \& Carrie Wells, Catalogue No. 97-553XIE (Ottawa: Statistics Canada, September 2007) at 6

${ }^{88}$ In particular see Miron v. Trudel, [1995] 2 S.C.R. 418 and M v. H. [1999] 2 S.C.R. 3; hereinafter $M$. v. $H$. 
which flow legal consequences closely assimilated, if not identical, to those that flow out of marriage. But it is not simply living together that attracts this marriage-like status. There is an ineffable something more that transforms housemates of one to three years into spouses.

Imbedded within the definition of cohabitation in different federal and provincial statutory regimes is a reference to "conjugality". So, for example, Ontario’s Family Law Act itself defines cohabitation as "liv[ing] together in a conjugal relationship, whether within or outside marriage”. Those who live together but are not in a conjugal relationship would be disqualified or exempted from any provisions that relate to spousal cohabitation. Someone with whom one lives non-conjugally (even beyond the 3 year mark) will not owe spousal support, will not be a pension beneficiary, will not be able to sue for one's wrongful death, will not inherit property when one dies intestate, and so on. This concept of conjugality, then, has become the proxy for determining what is spouselike or marriage-like behavior.

Presumably, the notion of conjugality would be of assistance for determining what it is to live "under the guise of marriage" for the purposes of the polygamy provisions, given the other elements that appear to have been read out of them. The concept of conjugality, however, has merely displaced the difficulty of understanding what is spouse-like or "under the guise of marriage" onto a term that is laced with ambiguity. The legal content of the concept has been filled in by judicial interpretation and that interpretation has shifted and changed over time.

There are two principal ways in which conjugality has been defined in common law, one subjective, the other functional. The first is now dated and the second is fairly confused. Both ways of construing what constitutes spouse- or marriage-like cohabitation are canvassed in a compelling article by Brenda Cossman and Bruce Ryder. ${ }^{89}$ Cossman and Ryder depict the test for the subjective equivalence of a relationship to marriage as one hinged upon whether an unmarried cohabiting couple have voluntarily embraced such a status. The touchstone of whether the relationship is conjugal is the nature of their subjective intentions. In the case of spousal support, for example, the test would rely upon whether the

${ }^{89}$ Brenda Cossman \& Bruce Ryder, "What is Marriage-Like Like? The Irrelevance of Conjugality” (2001)18 Can. J. Fam. L. 269. 
couple pledged to each other mutual support. ${ }^{90}$

This approach is now dated by virtue of the fact that courts have found it difficult to discern a common intention, either because the parties might have had different intentions, or they may have formed no clear intention at all over the course of the relationship's evolution. More important, however, was the emergence of the pressing policy objective to protect cohabitants (principally women) from the economic disadvantages that arise over the course of an interdependent relationship. These are the same concerns that allow courts to read constructive trusts into property owned by one spouse who has been unjustly enriched by the other spouse's unremunerated domestic contribution. The former spouse's subjective intention cannot be permitted to circumvent the economic interdependence and concomitant legal responsibilities that emerge from the way that the parties structure their relationship. As a result of this growing recognition of the intertwining of finances over the course of cohabitation, the subjective test has fallen out of judicial favour.

The functional equivalence test has emerged in tandem with the demise of the subjective approach. This approach to determining whether a relationship is marriage-like relies upon an identification of the basic dimensions and functions of a marital relationship to which the relationship in question is compared. The 1980 Molodowich v. Penttinen case $^{91}$ consolidates the functional attributes laid out in prior case law. Justice Cory, in the 1999 Supreme Court case of $M$. v. H., recapitulates and endorses the Molodowich approach when he notes that "the generally accepted characteristics of a conjugal relationship...include shared shelter, sexual and personal behavior, services, social activities, economic support and children, as well as the societal perception of the couple." Not all of these elements will necessarily be present in all married relationships.

The functional equivalence of conjugality with this loose agglomeration of marital attributes is not without its problems. Cossman and Ryder underline these drawbacks and argue that the concept of functional equivalence to marriage has grown increasingly tenuous in the light of jurisprudential developments.

The first attenuation of the test derives from the dissociation of

\footnotetext{
${ }^{90}$ ibid at p. 284

${ }^{91} 17$ R.F.L. 9 (2d) 376
} 
sexual relations and conjugality - generally thought popularly to be the latter's sine qua non. As Cossman and Ryder note, Canadian judges have begun to find conjugality in the absence of sexual relations. Alongside Justice Cory's views on this matter in $M$. v. $H$. they cite the 1990 Richardson case in which the judge held that "[t]he parties may, for a number of reasons, such as age, illness or indifference, choose not to have sexual relations but still live together and hold themselves out to be husband and wife in other respects. For that reason, it is my view that the trial judge was wrong to have made sexual relations between the parties a requisite for a conjugal relationship." ${ }^{92}$ As much as this dissociation of conjugality from sexual relations leaves the functional equivalence test more baffling for family law, it makes it that much more difficult to discern the mischief in the polygamy provisions.

Another drawback of the functional test, not just for a finding of polygamy but for all legislative regimes that rely upon the concept of conjugality, is the privacy-violating nature of the inquiries that courts must pursue to establish it. This is most evident with respect to the dimensions of sexual and personal behavior to which Justice Cory alludes. Although sexual relations may not be necessary to a finding of conjugality using the Molodowich criteria, the functionalist approach has led courts to engage in a strikingly intrusive (if not unseemly) set of questions. The judge in the 1978 case of Stoikiewicz v. Filas illustrates the type of questioning that one couldn't make up to better drive home the point about unseemliness:

Q: Mrs Stoikiewicz, did you live with Mr. Filas as husband and wife?

A: That's the way it was.

Q: Did you share the same bedroom?

A: No.

Q: I see. Did you have sexual relations with each other?

A: Yes.

Q: Was it frequent or just occasional?

A: Occasional. From time to time.

Q: Did you cook his meals?

A: I cooked for him. ${ }^{93}$

${ }^{92}$ Richardson v. Richardson, (1990), 107 N.B.R. (2d) 49

${ }^{93}$ Stoikiewicz v. Filas, (1978), 7 R.F.L. (2d) 366 
The actual finding in Stokiewicz was that a conjugal relationship did not exist despite the answers to these questions. More to the point than the eventual finding is nature of the inquiry upon which the court had to embark to establish it. Taking into account that the polygamy provisions permit swinging and adultery, it is easy to imagine that the hair-splitting distinctions between this monogamy-commensurate behavior and sexual and personal relations that are not could only become more unseemly and offensive.

It is worth reiterating at this point that the concern about the unseemliness and intrusiveness of inquiries into the kind of sexual activity that goes on behind the doors of polygamous unions are, in any event, verboten for establishing the crime of polygamy. As argued above, the Labaye case has made clear that sexual activity with multiple consenting partners (including spouses), provided it is conducted in private, does not constitute the secular harm in polygamy. There is nothing in the sexual activity of polygamy that rises to an act of indecency; certainly not if swinging and private orgies with (or without) one's spouse is not indecent.

While the job of a family law judge may be made harder by the reference to sexual activity as a recurrent commonality in conjugal unions, the job of a criminal law judge looking for proof of conjugality for the purposes of "any conjugal union” is made lighter by Labaye's elimination of consensual adult sexual activity from the set of mischiefs that might constitute the criminal act of polygamy. The elimination of sexual activity from the repertoire of harms embedded within "any kind of conjugal union with more than one person at the same time" further renders "conjugality" into a vapidity for criminal law.

There is one further drawback to which Cossman and Ryder point that perhaps far more swiftly demolishes the use of the concept of conjugality for the polygamy provisions. As they note, none of the criteria in the functional-equivalence test are essential. The test does not provide a kind of bright line distinction between conjugal and non-conjugal relationships. Citing Justice Cory, they note how the test has become extraordinarily open-ended: "In order to come within the definition, neither opposite-sex couples nor same-sex couples are required to fit precisely the traditional marital model to demonstrate that the relationship is conjugal....Courts have wisely determined that the approach to determining whether a relationship is conjugal must be flexible. This must 
[VOL. 05 No. 01

be so, for the relationships of all couples will vary widely."94

While the flexibility inherent in this test allows courts to find conjugality where there is not an exact equivalence with an ideal model of marriage, the result is an astonishing lack of clarity that impedes the ability of couples to anticipate when they do or do not qualify. As Cossman and Ryder point out, "in sacrificing clarity and predictability for flexibility and diversity, the judicial understanding of conjugality now comes close to a "I know it when I see it" approach."95

For the hypothetical Catholics or Jews cited above, ${ }^{96}$ who are civilly married to one spouse and religiously to another, are they now legally free to share a residence between the three adults, pooling domestic tasks and assets, and raising the children of each marriage together? Parties in plural cohabitational relationships might ask the same question. What if they don't share childcare, or if they parcel off domestic tasks and assets to separate individuals? What if they share everything but live next door to each other and, a la Big Love, ensure the public has no social perception of their private arrangement? Will a judge find that flexibility and diversity in the concept of conjugality warrant toleration of such arrangements? Will sexual activity (and its frequency) between the adult members of the household increase the chance that a judge will find plural conjugal unions within it? Or will that activity be legally irrelevant, shielded by privacy?

The conceptual looseness in the concept of conjugality may be problematic for family law - it is poised to be fatal for criminal law.

If the state cares enough to make a distinction between swinging, adultery, and polygamy - cares sufficiently that it is prepared to attach potential jeopardy of five years imprisonment to the behavior - then a reasonable person should be able to foresee when their behavior enters the prohibited zone. They should not have to wait upon the intuitions of an oracular judge.

\footnotetext{
${ }^{94}$ M. v. H. para 60

${ }^{95}$ Supra, note 90 at 299

${ }^{96}$ In the section "Religious Diversity"
} 


\section{VOID FOR VAGUENESS}

Let me recapitulate where this paper has gone before concluding whether the current polygamy provisions are void for vagueness:

Religious marriage to one person can co-exist with civil marriage to another in Canadian family law without the former constituting a "lawful impediment" to the creation of the latter - and without those plural unions constituting "any form of polygamy" or multiple "conjugal unions with more than one person at the same time."

Religious marriages are nullities in both civil and criminal law. Criminal law does not prohibit the parallel existence of religious marriages, even though they may be never formalized in a civil ceremony. Marriages celebrated in Canada "in non-monogamous form without a preceding ceremony in accordance with Canadian provincial law [are regarded] a[s] nullit[ies]."97 Religious marriages are carved out as an exception to the definition of "forms of marriage" in the bigamy provisions of the Criminal Code and cannot give rise to "any form of polygamy" or "any kind of conjugal union" for the purposes of the polygamy provisions. A plurality of nullities constitutes a nullity. Canada tolerates plural religious marriage both de facto and in law.

For Aboriginal Canadians alone, consent constitutes marriage and living together constitutes consent to create a "conjugal union" for the purposes of the polygamy provisions. Apparently Aboriginal people commit polygamy when they sleep over night at a house shared by two other adults, whether or not they derive the pleasure of swinging together at the same time.

On the logic of Tolhurst, adultery is not a conjugal union which is "under the guise of marriage" for the purposes of polygamy. A long-term relationship with one person while civilly married to another is not polygamy even if the relationship meets the current statutory definition of unmarried cohabitation. Adulterous cohabitation with one person while civilly married to another does not generate multiple "conjugal unions" for the purposes of the Criminal Code provisions (unless, apparently, one is Aboriginal).

Polyamory is consistent with monogamy. There is no common law

${ }^{97}$ Qureshi v. Qureshi; see also Castel and Walker, supra, note 44 at section 16.6 
[VOL. 05 No. 01

or statutory threshold for when a polyamourous relationship becomes a polygamous one, except the problematic modern conception of conjugality. Sexual activity is not the mischief in the polygamy provision.

The common law definition of conjugal union has no essential elements. The cluster of "marriage-like" features are intentionally flexible and judges are left to "know one when they see one". Conjugal unions do not need to be sexual in nature to exist. Nor need the parties to a conjugal union share a residence, pool domestic tasks and assets, or have generated a social perception of conjugality.

Taking into account all of these statutory and jurisprudential understandings of what constitutes a "form of marriage", "any form of polygamy", and "any kind of conjugal union, whether or not it is by law recognized as a binding form of marriage" it becomes virtually impossible to articulate what the secular conception of bigamy or polygamy amounts to and what the core mischief is that underlies it; virtually impossible for the provisions to constitute fair notice that particular conduct falls within the scope of the offence.

The Supreme Court has established that a vague law offends the principles of fundamental justice under s. 7 of the Charter because

[i]t is essential in a free an democratic society that citizens are able, as far as is possible, to foresee the consequences of their conduct in order that persons be given fair notice of what to avoid, and that the discretion of those entrusted with law enforcement is limited by clear and explicit legislative standards...This is especially important in the criminal law, where citizens are potentially liable to a deprivation of liberty if their conduct is in conflict with the law. ${ }^{98}$

The difficulty with the ways in which the current Criminal Code provisions have been interpreted and the ways in which they have interacted with or been overtaken by developments in private law has precluded reasonable foresight into what is legal and what is illegal behavior with multiple partners. It is now extremely difficult to articulate the sensible meanings of "conjugal union" or "form of marriage" in light

\footnotetext{
${ }^{98}$ Prostitution Reference at para 30
} 
of the socio-legal history that has emerged over the 117 years since the provisions were first drafted.

The provisions on their own are astonishingly overbroad ("any form of polygamy"; "any kind of conjugal union whether or not it is by law recognized as a binding form of marriage”). For example, a party in the not uncommon situation of living separate and apart from a civil spouse while waiting for a civil divorce, and who begins to live with another spouse with whom he or she wants to build a life, is captured by the provision. ${ }^{99}$

Far more fatally for any claims that the language of the provision is not overbroad is the radical dissonance between the proclaimed contemporary objective of the provision and its consequences. Protecting the vulnerabilities of women and children is commonly taken to be the pressing and substantial objective that replaced religious discrimination in the Criminal Code amendments to polygamy in the 1950s. ${ }^{100}$ And yet, not only is the net cast broadly over a vast range of relationship configurations, it is calibrated to catch "every one" who is in one of these forbidden relationships.

"Every one" includes women in plural marriages. As has been argued effectively elsewhere, these women are not only in just as much jeopardy as men to spend five years in prison (all to protect their own better interests), the criminalization of their relationships also renders them far less likely to come forward and assert their rights under areas of law that do protect their vulnerabilities such as division of matrimonial property, spousal support, and child support. ${ }^{101}$

The overbreadth of a provision's reach is a concern that is closely related to its potential vagueness. Both concerns form the basis of "the minimum standard for the formal content of law demanded by principles of fundamental justice". ${ }^{102}$

${ }^{99}$ For the jurisprudential understanding of what makes a provision overbroad, see $R$. $v$. Heywood

100 See Cook, supra, note 31; also see Bala’s argument, supra, note 31

${ }^{101}$ See Bailey et al, supra, note 16 at 17

102 Jamie Cameron and James Stribopoulos (eds), The Charter and Criminal Justice; Twenty Five Years Later, (Toronto: LexisNexis Canada, 2008) 
This overbreadth in the polygamy provisions makes them susceptible to being "so devoid of precision in its content that a conviction will automatically flow from the decision to prosecute", the criteria that Gonthier used for a law being void for vagueness. ${ }^{103}$ The provisions thus not only open a door to a "standardless sweep", they open the door for "law enforcement officials to pursue their personal predilections". ${ }^{104}$

As noted above, Lamer, in writing a key Supreme Court discussion on the void for vagueness doctrine, is clear that it does not require that a law be absolutely certain. Further he noted that the doctrine "is not be applied to the bare words of the statutory provision but, rather, to the provision as interpreted and applied in judicial decisions." ${ }^{\text {105 }}$ After reviewing how the provisions have been jurisprudentially understood, alongside the statutory and jurisprudential framework in proximate bodies of law, it is hard to see how the provisions, as they have been worked with and around over the last century, give sufficient guidance for legal debate, the criteria for void for vagueness set by Mr. Justice Gonthier in the leading case of Nova Scotia Pharmaceutical Society. This is particularly so in the absence of extensive judicial interpretation that might have narrowed the scope of the section. ${ }^{106}$ In the case of polygamy, it is probably fair to say that there is no meaningful judicial interpretation that can be relied upon, Bear's Shin Bone being dependent upon a concept of customary marriage that is restricted to Aboriginal people and Tolhurst being woefully out of date with contemporary understandings of unmarried cohabitation.

Not only are the polygamy provisions astonishingly overbroad, all manner of exceptions have been carved out of their original breathtaking reach (swinging, adultery, unmarried cohabitation, religious marriage, etc) such that what remains is barely an incoherent pile of scraps held together by a common law thread ("conjugality") that is itself frayed and torn and

\footnotetext{
${ }^{103}$ R. v. Nova Scotia Pharmaceutical Society at 636

${ }^{104}$ Both of these dangers were critiqued in Mr. Justice Lamer's disquisition on void for vagueness in the Prostitution Reference, at para 30

${ }^{105}$ Prostitution Reference, at para 30, citing Lebeau (1988) 62 C.R. (3d) 157 at 167

${ }^{106}$ Nova Scotia Pharmaceutical Society at paras 22-23
} 
that does not tie the concept into place when conjoined with the fact that unmarried cohabitation, adulterous affairs, and religious marriages are not "conjugal unions" for either the polygamy provisions nor are they "lawful impediments" to civil marriage.

While it is clear that no law can meet the standard of absolute certainty, both the principles of fair notice to citizens (particularly for criminal law where individual liberty is in jeopardy) and the limitation of enforcement discretion indicate strongly that the current polygamy section offends the principles of fundamental justice set out in s. 7 of the Charter. This is particularly so in light of a massive shift in the substratum of values regarding family and sexuality over the last 40 years - a substratum accessible to all Canadians who might otherwise lack access to the technicalities of formal notice; a substratum that also provides the moral foreseeability of harm while generating the substantive notice that innoculate legal enactments from claims of arbitrariness. ${ }^{107}$

The deficiencies in the polygamy and bigamy laws swing between astonishing overbreadth and vagueness. What remains are provisions that seem poised to encourage arbitrary and erratic arrests and convictions, particularly when conjoined with the fact that the provisions were originally drafted in 1892 to catch fundamentalist Mormons, ${ }^{108}$ that a disproportionate number of those convicted under the provisions have been Aboriginal people, and that public pressure to prosecute is directly mostly at religious groups.

Bearing in mind case law, subsequent statutory law in a range of fields, and social developments over the last century, it becomes extraordinarily difficult to state what the secular conception of polygamy amounts to, apart from a mechanism to discipline and convict socially and politically marginal groups.

I do not think there is a way to salvage the polygamy provisions; to give "sensible meaning" to their terms, in the language of one of the

${ }^{107}$ See the criteria laid down by Justice Gonthier in the leading case on the doctrine of void for vagueness: $R$. v. Nova Scotia Pharmaceutical Society at para 48

108 See Bala, supra, note 31: "Polygamy has been illegal in Canada since 1892. This provision was enacted in Canada as part of the first Criminal Code, apparently as a result of American influences, as criminal laws were being enacted about that time in the United States to prohibit the practice of polygamy by members of the Mormon Church.” At p. 28. 
[VoL. 05 No. 01

leading cases on void for vagueness. ${ }^{109}$ If the provisions are nullified by the courts then it will be up to Parliament to come up with a modified definition of polygamy that captures whatever acceptable mischief remains once the original objective has been excised. ${ }^{110}$ Parliament won't have a clean slate to create a new polygamy law. It will have to legislate on top of the landscape of the entire statutory and jurisprudential history I have elaborated above - a history that would force Parliament into navigating the inconceivably narrow straits left behind by all of the exceptions that I have laid out above.

The exercise of distinguishing the peculiarly secular mischief in polygamy after the jurisprudential erosion of content over the last century leaves those who want to defend it - and not me - in the position of counting angels on the residual pinhead of the bare statutory words. The Christian imagery of the angel-counting, alongside the Christian history out of which the polygamy provisions emerged, should leave us a bit cautious about such an undertaking.

\section{RESIDUAL SECULAR PURPOSES}

On the above analysis, it seems clear that the polygamy provisions of the Criminal Code are unconstitutional under section 7 of the Charter. An argument under section 1 of the Charter that there is a pressing and substantial objective that should override our concerns about the violation of citizens' constitutionally entrenched rights to security may be imperiled by the original objective animating the prohibition, which was to isolate and prosecute religious minorities. The unsavory history of the selective use of the provisions against Aboriginal people supports the idea that the polygamy provisions were crafted as a means of persecuting and disciplining socially and politically marginal groups. If there is an

${ }^{109}$ Prostitution Reference

${ }^{110}$ Obviously I am assuming that Parliament will not invoke the notwithstanding clause, which it did not seriously contemplate doing for same-sex marriage and cannot contemplate doing without violating a longstanding customary prohibition on invoking a clause that allows Parliament to pass legislation that unequivocally violates fundamental human rights. 
alternative pressing and substantial objective, it has to overcome the historical suffusion of the polygamy provisions with the utterly unacceptable original objective, which had religious minorities in its sights.

A question remains as to whether the criminal prohibition of polygamy is a proportionate response to the concerns raised in a more contemporary formulation of the objective driving the section: the protection of the emotional and financial vulnerabilities of women and children living in polygamous unions. This objective is consistently advanced as a sufficiently pressing and substantial one to override concerns about other Charter rights violations. ${ }^{111}$

I will concede, because I readily perceive it to be true, that this is not a frivolous objective with little or no social import. Far from it. The protection of vulnerable women and children from the asymmetries inherent in plural marriages (which are virtually always polygynous rather than polyandrous) is an objective that has accrued a great deal of scientific support in the last several decades. There are an abundance of reports from around the world that support the voices of women who have fled from, or feel trapped within, polygamous unions. ${ }^{112}$

Further, this objective is embodied in the 1992 United Nations Convention to Eliminate all forms of Discrimination Against Women (CEDAW) which in its General Recommendation on Equality in Marriage and Family Relations urges that, "Polygamous marriage contravenes a woman's right to equality with men, and can have such serious emotional and financial consequences for her and her dependants that such marriages ought to be discouraged and prohibited."

Canada, as a signatory to the CEDAW, has committed itself to "take all appropriate measures to eliminate discrimination against women in all matters relating to marriage and family relations." 113 How, then, can Canada uphold this international commitment - and uphold its legitimate animating aspiration to liberate women and their dependents from the

${ }^{111}$ See Cook et al, supra, note 31 and Bala, supra, note 31

${ }^{112}$ For a particularly committed presentation of this case, see Cook et al, supra, note 31; For a review of this literature, also see Bailey et al, supra, note 16.

${ }^{113}$ Article 16, CEDAW. 
serious emotional and financial consequences that can arise from polygamy? Is criminalizing plural marriage the only means of meeting that international commitment? Is it the most effective?

As already argued, the overbreadth of section 293, in catching "every one" who engages in a plural union, is radically at odds with the feminist objective: women in plural unions are subject to being torn away from their children for up to five years in a federal penitentiary, their children deprived of a mother for a yawning black hole of time - just as they stand to be deprived of their fathers. The stigma of criminal prosecution and conviction (and in the case of Bountiful, very public scrutiny and shaming in the national media) can only add to the burdens of the very parties that the law purports to protect. Further, the deprivation of either one or both parents leaves children poised to experience extreme levels of emotional and financial turbulence. The criminalization of both parties to the union also adds a thick layer of wariness and caution to any aspirations such women might entertain about the state's safety net capturing their fall should they exit the relationship.

These contradictions between the polygamy provisions and their purported objective strongly suggest that the criminalization of plural unions is not the least drastic means for meeting that objective. ${ }^{114}$ It is hard to think of a more drastic intervention to protect the vulnerabilities of women than their potential incarceration and removal from their children.

Are there other, less punitive means of meeting the objective of lightening the miseries and inequalities to which plural forms of marriage may be prone? Would these means impair less the security rights of Canadians to be free from the arbitrary prosecution that is inherent in vague criminal provisions? Would they impair less the rights of religious minorities to the free expression of their spiritual preferences? If this is the case, then the minimal impairment test of section 1 of the Charter will not be met by the current polygamy provision.

Let me suggest that there are an abundance of such measures, many of which are already in place merely awaiting the removal of criminal stigmatization in order for women in oppressive plural unions to exit the relationship with the same confidence as women in oppressive monogamous unions.

\footnotetext{
${ }^{114}$ As per the requirements of the minimal impairment test of section 1 of the Charter.
} 
A substantial movement towards the objective has already been met by ensuring that civil consequences such as spousal support flow from the factual reality of all relationships that endure for the statutory period of cohabitation for common law spouses (generally two to three years, depending on which federal or provincial statute is in play; and/or relations of some permanence with a child). Whether or not a union has been polygamous these entitlements flow from the duration of the relationship. This de facto entitlement to spousal support also computes with the new Federal Spousal Support Advisory Guidelines, which root the entitlement to spousal support in the duration of the relationship and the parenting obligations that parties incur. ${ }^{115}$

Another substantial movement flows from fact that child custody and child support is not dependent upon the legitimacy of the form of marriage. Family law legislation across Canada's provinces brought about an end to the distinction between legitimate and illegitimate children in the 1970s. Child support obligations are linked to the biological relationship between parents and their children, as well as the social relation between children and those parents who stand in loco parentis (in the place of a parent). ${ }^{116}$

The fact that parties to a polygamous union are entitled to use the constructive trust doctrines to establish a beneficial interest in accumulated marital property if they can establish a contribution to it makes it easier for all women to exit degrading and abusive relationships, whether or not those unions are polygamous or monogamous.

Legislation such as the Ontario Family Law Act already includes, in the definition of those spouses who have access to the default property regime of married spouses, marriages that are actually or potentially polygamous, if they were celebrated in a jurisdiction whose system of law recognizes it as valid. ${ }^{117}$ If courts (which have yet to weigh in on what this provision means) were to interpret the section to mean that all polygamous

\footnotetext{
115 See the federal Spousal Support Advisory Guidelines July 2008, (C) Carol Rogerson and Rollie Thompson, 2008; online at: http://www.justice.gc.ca/eng/pi/padrpad/res/spag/index.html

${ }^{116}$ See section 2(2)(a) of the Divorce Act.

${ }^{117}$ Section 1(2) of the Family Law Act.
} 
marriages, whether or not they are formed in Canada, give rise to rights in the default statutory marital property regime, this would bolster the ability of women in polygamous unions to exit without confronting the debilitating fear of poverty.

Of course it would also help to eliminate the inequities and grave emotional and financial consequences of polygamous marriage for women if provincial social assistance rates were raised to such an extent that abused women across Canada didn't feel that remaining in an abusive relationship is preferable to the indignities and acute deprivations of welfare. ${ }^{118}$

And all oppressed wives, whether in common law relationships, monogamous marriages, or polygamous unions would be lifted by the rising tide of a sorely needed national daycare system that would permit single mothers to work or train for work while leaving their young children in affordable and adequate child care arrangements.

All of these measures (and many more) would go (and have gone) a substantial way to meeting Canada's commitment under the CEDAW to "take all appropriate measures to eliminate discrimination against women in all matters relating to marriage and family relations", whether those women are in plural or monogamous unions.

There is another measure that Canada could take, however, that would entrench - in a more global, albeit symbolic, way - its specific international commitment with respect to polygamy. And Parliament could do so in a manner that might well skirt the constitutional problems that plague the polygamy provisions:

Canada could leave the Civil Marriage Act in place, untouched, and modify the bigamy provisions so that they unequivocally state that the only form of criminally prohibited plural union is two simultaneous civil marriages to different partners.

The Civil Marriage Act already only refers to marriages "for civil purposes" and confines them to monogamous unions. The bigamy provision already appears, on a reasonable interpretation of it, to uniquely prohibit everyone who is civilly married from entering another civil marriage to another person. The section need only be cleaned up to

${ }^{118}$ See Janet Mosher’s report, “Walking on Eggshells: Abused Women's Experiences of Ontario's Welfare System” Final Report of Research Findings from the Woman and Abuse Welfare Research Project, April 5, 2004. 
explicitly meet this objective - the objective of maintaining clarity around the status of civil marriage. This latter objective may continue to have value if Canadians continue to prefer (as they appear to do by an increasingly narrow margin) $)^{119}$ civil marriage to unmarried cohabitation. All bigamous civil unions would be captured by this newly clarified bigamy provision - leaving things like religious marriages, adultery, and "mistresses" alone as none of the state's business. Each of the latter would remain capable of acquiring benefits under the status of unmarried cohabitation or spouse under statutory and equitable regimes.

For good measure, Parliament could also finally occupy the jurisdictional field it was given in 1867 and stipulate a minimum age requirement for consent to marriage while entrenching the common law requirement for bilaterality as a necessary condition between marriage partners. These legislative modifications would reflect the prevailing Canadian sensibility about the precious, yet vulnerable, integrity of young people and the vital importance of women's agency within married life. They would find further legitimacy in the broader social policies that have consolidated amongst the community of nations. Canada's commitment to this larger community is embodied in its formal assent to CEDAW's provisions requiring the government to ensure that women and men have the same right to enter marriage and the same right to freely choose a spouse and to enter marriage only with their free and full consent. ${ }^{120}$

All of this is contingent on the Canadian state continuing to care whether it regulates what has become an almost purely symbolic institution: civil marriage. As the state now recognizes all of the forms of economic interdependence formally captured by the institution of marriage (through, for example, unmarried cohabitation, constructive trust, and third party rights and obligations relating to cohabiting spouses), only residual amounts of light can be seen between civil marriage and

${ }^{119}$ Quebec is now the leading province in the direction away from the preference for civil marriage over unmarried cohabitation. Over 30\% of couples in Quebec are in civil unions. This is two and a half times the rate in other provinces and territories (34.6\% by comparison with 13.4\%). See Statistics Canada, "Family Portrait: Continuity and Change in Canadian Families and Households in 2006, 2006 Census”, by Anne Milan, Mireille Vézina \& Carrie Wells, Catalogue No. 97-553-XIE (Ottawa: Statistics Canada, September 2007) at 7

${ }^{120}$ Article 16 (a)(b) of the CEDAW. 
unmarried cohabitation. ${ }^{121}$ The gesture of continuing to legislate and regulate civil marriage would be a purely symbolic tip of the hat to Canada's commitment under the CEDAW.

Already arguments have been raised about whether even this bare commitment to civil monogamy can be constitutionally sustained. ${ }^{122}$ As noted in the "Charter Trouble" section of this paper, the right to liberty secured under section 7 of the Charter, implicating the fundamental liberty to choose which partner one marries - and also how many - may be in competition with any pressing and substantial objective of clarifying the status of civil marriage or symbolically entrenching the Women's Convention in the Civil Marriage Act and bigamy provisions.

And in any event, the specific harms associated with sexual integrity that are now voiced in the concerns about a minimum age for, and consent to, valid marriages are already captured in the prohibitions on sexual exploitation and sexual interference, and the post-1983 removal from the Criminal Code of marriage as a defense to sexual assault. All of these offences may indeed be easier to establish were they not hidden behind the thick veil of legitimacy and privacy provided by the institution of marriage. Entrenching a definition of monogamy for the purposes of both criminal and family law may be merely symbolic, but its symbolic freight can occlude some of the most pernicious harms that the entrenchment of the CEDAW in civil and criminal definitions of marriage was intended to prevent.

${ }^{121}$ Access to the default property regime for marital property is the most significant remaining difference following Nova Scotia v. Walsh, [2002] 4 S.C.R. The constructive trust regime, to which unmarried cohabitants have access on dissolution of their relationship, approximates the presumption of equal sharing in the default regime to which married couples have access. However acquiring a constructive trust in a cohabitating spouse's assets is a less certain outcome and the regime provides more latitude for judicial departure from presumed equality of contribution. As Rollie Thompson notes, "the law in this area has become more incoherent, inconsistent and unpredictable. Vague tests of "juristic reason" and "direct link" and "value received/survived" leave much room for subjective and stereotyped interpretations of roles and contributions.” 2003, 32 R.F.L. $\left(5^{\text {th }}\right)$ 87, at 92 . The gap between the default regime and constructive trusts is one that is felt by women in both monogamous and polygamous cohabitational relationships.

${ }^{122}$ See Bailey et al, supra, note 16 at 17 
Whether or not Parliament were to define civil marriage as monogamous in both the Civil Marriage Act and the Criminal Code, with the abundance of means at Parliament's disposal to meet its legitimate commitment under the CEDAW and the justified concerns about women's rights that have transformed the landscape of Canadian family over the last 40 years, the moral perils inherent in the criminalization of polygamy need to be deeply weighed and re-considered.

In light of the history of the jurisprudential history of the polygamy provisions and the massive changes to our apprehensions of what constitutes a legitimate, acceptable, and/or tolerable family and intimate life over the last 40 years, the climate of generalized anxiety about possible misconduct in the community of Bountiful has to be seriously reevaluated. It is hard not to see the glaring hypocrisies of those apprehensions in the light of all of the extensive and elaborate tolerances that have been carved out of the polygamy provisions since 1892. If Canadian law needs some adjustments to ensure that all women, including women in polygamous unions, have equal access to the concrete securities that make our options tangible and realizable - providing us with the most robust exercise of our agency that Canadian society is able to offer - then that should be done in a manner that does not single out religious, social, and political minorities for a singular form of scrutiny, discipline, persecution, and paranoia. 